Western University

Scholarship@Western

Civil and Environmental Engineering

Civil and Environmental Engineering

Publications

Department

2018

Seismic performance of modular steel frames equipped with shape memory alloy braces

Papia Sultana

Western University

Maged A. Youssef

Western University, youssef@uwo.ca

Follow this and additional works at: https://ir.lib.uwo.ca/civilpub

Part of the Structural Engineering Commons

Citation of this paper:

Sultana, Papia and Youssef, Maged A., "Seismic performance of modular steel frames equipped with shape memory alloy braces" (2018). Civil and Environmental Engineering Publications. 191.

https://ir.lib.uwo.ca/civilpub/191 


\title{
Seismic performance of modular steel frames equipped with shape memory alloy braces
}

$$
\text { Papia Sultana }{ }^{a} \text {, Maged A. Youssef }{ }^{b}
$$

Western University, Civil and Environmental Engineering, London, ON N6A 5B9, Canada

\begin{abstract}
The demand for modular steel buildings (MSBs) has increased because of the improved quality, fast on-site installation, and lower cost of construction. Steel braced frames are usually utilized to form the lateral load resisting system of MSBs. During earthquakes, the seismic energy is dissipated through yielding of the components of the braced frames, which results in residual drifts. Excessive residual drifts complicate the repair of damaged structures or render them irreparable. Researchers have investigated the use of superelastic shape memory alloys (SMAs) in steel structures to reduce the seismic residual deformations. This study explores the potential of using SMA braces to improve the seismic performance of typical modular steel braced frames (MSBFs). The study utilizes incremental dynamic analysis (IDA) to judge on the benefits of using such a system. It is observed that utilizing superelastic SMA braces at strategic locations can significantly reduce the inter-storey residual drifts.
\end{abstract}

Keywords: Modular steel building, Shape memory alloy, Seismic performance, Incremental dynamic analysis, Inter-storey drift, Residual drift.

${ }^{a}$ PhD Candidate, Western University, Civil and Environmental Engineering, London, ON, Canada N6A 5B9, Email: psultana@uwo.ca.

${ }^{\mathrm{b}}$ Professor, Western University, Civil and Environmental Engineering, London, ON, Canada N6A 5B9.

Corresponding author: Maged A. Youssef, Email: youssef@uwo.ca, Tel.: 519-661-2111 Ext. 88661. 


\subsection{INTRODUCTION}

Modular construction is the preferred choice, when repetitive units are required as in schools, hospitals, hotels, etc. One to six storey modular steel buildings (MSBs) usually rely on bracing elements for lateral stability. Figure 1 shows a plan view of a typical MSB along with the horizontal and vertical connections between the modules [1]. Annan et al. [1-2] emphasized that the seismic performance of modular steel braced frames (MSBFs) is significantly different from regular steel braced frames. Such difference is attributed to the existence of ceiling beams, the eccentricity developed at the joints as the braces do not intersect at a single working point, and the semi-rigid connections between the columns of a module and the ones above or below it.

The design philosophy of regular steel braced frames ensures that plastic deformations occur only in the braces, leaving the beams, columns, and connections undamaged. As a result, steel braced frames are expected to survive strong earthquakes, and dissipate the seismic energy through ductile yielding of tension braces and buckling of the compression braces. The conventional steel bracing system has limited ductility and energy dissipation capacity due to buckling and asymmetric behavior of the tension and compression braces.

Buckling restrained braced frames (BRBFs) offer an alternative to conventional braced frames and surpass their energy dissipation capacity. Each buckling restrained bracing (BRB) has two basic components: a steel core that supports the entire axial force, and an exterior element that prevents the core from buckling. Although, seismic damage to BRBFs is concentrated in the core, which can be easily repaired; they are still susceptible to residual drifts [3-5]. 
Superelastic shape memory alloys (SMAs) attracted the attention of researchers in recent years because of their ability to dissipate the seismic energy, while maintaining the self-centering ability. SMAs, based on Nickel Titanium (NiTi), were found to be the most suitable for most commercial applications [6]. Researchers had investigated the seismic performance of steel and reinforced concrete frames equipped with SMA braces [7-17]. MaCormic et al. [9] analytically studied the performance of steel frames equipped with SMA braces. Such braced frames were found to be effective in limiting inter-storey drifts (IDs) and residual inter-storey drifts (RIDs) following an earthquake. Kari et al. [10] investigated numerically the benefits of using a combination of buckling restrained braces and SMA braces in new designs as well as retrofitting cases. Results revealed that residual inter-storey drifts can be minimized using such a system. The seismic behavior and performance of self-centering buckling-restrained braces (SC-BRBs) that utilize SMAs were investigated by Eatherton et al. [13]. The SC-BRB consisted of a typical BRB and pre-tensioned superelastic NiTi SMA rods. The study revealed that SC-BRBs are capable of reliably limiting residual drifts. The seismic performance of SMA-braced frames with different bracing configurations was also studied [14-16]. Ghassemieh and Kargarmoakhar [17] assessed the seismic response of SMA braced frames in terms of response modification factor (R), overstrength factor $\left(\mathrm{R}_{0}\right)$ and ductility factor $(\mathrm{R} \mu)$. Pushover analysis was performed to determine $\mathrm{R}_{0} . \mathrm{R}_{\mu}$ was determined from both linear and nonlinear time history analyses. Their study recommended using a value between 5.77 and 9.68 for the response modification factor, $\mathrm{R}$, for different types of SMA braced frames. 

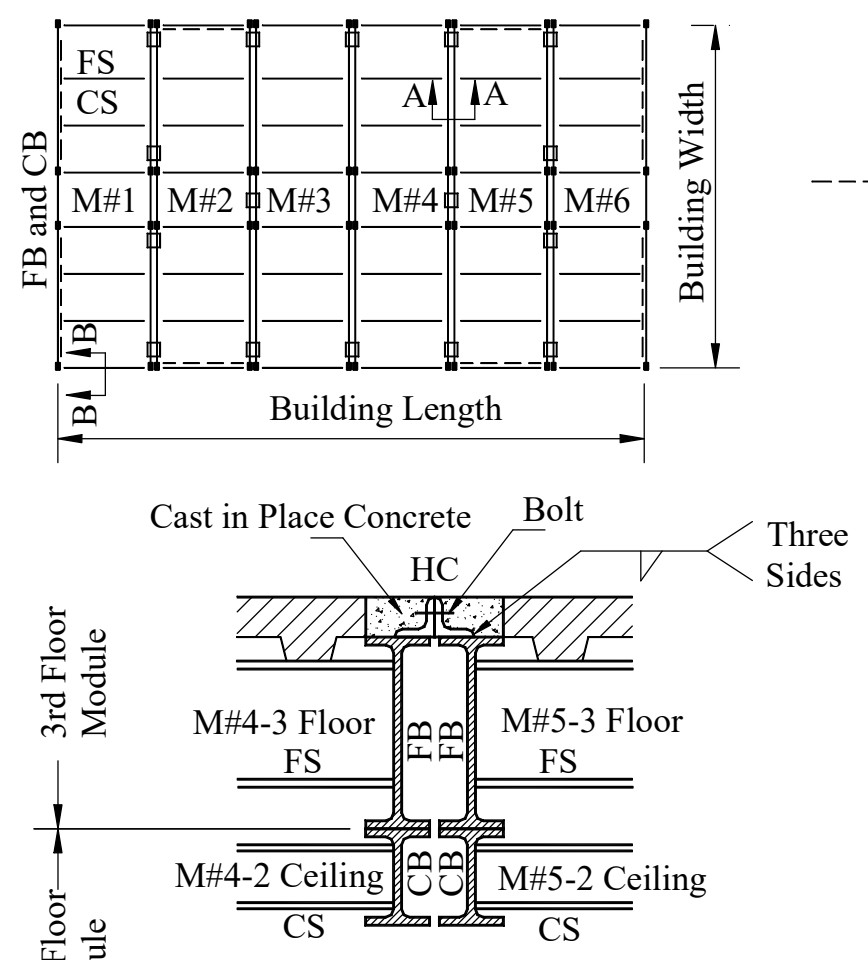

Sec. A-A: Horizontal Connection
Symbols:

Column

Horizontal Module Connection

Braced Frame

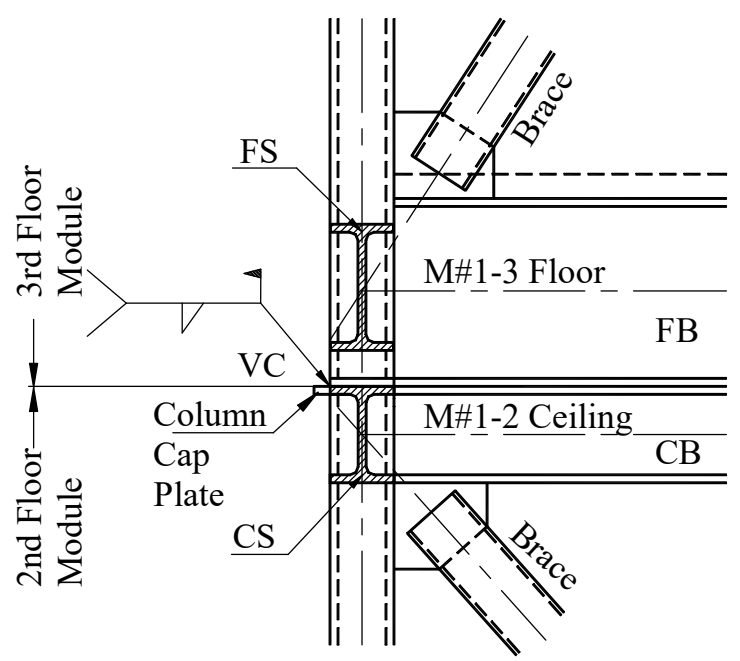

Sec. B-B: Vertical Connection

FS-Floor Stringer

CS-Ceiling Stringer

FB-Floor Beam

CB-Ceiling Beam

HC-Horizontal Connection

VC-Vertical Connection

Figure 1: A typical plan and section of a modular steel building [1]

Although few research data on using SMA in steel braced frames can be found in the literature, previous research did not address their use in MSBs. Sultana and Youssef [18] identified the required location of SMA connections in a typical steel moment resisting frame. Their study concluded that the best seismic performance can be achieved by utilizing SMA connections at few chosen locations of the frame. This study extends this research by exploring the seismic performance of MSBFs equipped with buckling restrained SMA braces and identifying the desired 
locations in this case. The finite element modeling technique, adopted in this study, was first validated using available experimental studies. Incremental dynamic analysis of a MSBF, that is equipped with buckling restrained steel braces, was performed considering five different ground motions. The steel braces were then replaced by buckling restrained (BR) superelastic SMA braces. Five different configurations of BR-SMA braces were examined. The seismic performance of the analyzed frames was then compared in terms of maximum inter-storey drift (MID), maximum residual inter-storey drift (MRID), and damage distribution to identify the BR-SMA brace configuration resulting in the best seismic performance.

\subsection{MODULAR STEEL BRACED FRAME}

The six-storey modular steel building (MSB), located in Vancouver, British Columbia, Canada, was selected as a case study. It was designed by Annan et al. [1] according to the Canadian standard CSA-S16-01 [19] and the National Building Code of Canada [20]. The seismic design was based on uniform hazard values corresponding to a $2 \%$ in 50 -year probability of exceedance. The soil was assumed as site Class C, having an average shear wave velocity of $360 \mathrm{~m} / \mathrm{s}$ to $760 \mathrm{~m} / \mathrm{s}$. The overstrength and ductility factors were equal to 1.3 and 3.0, respectively. Superimposed dead load of $0.75,0.32$, and $0.7 \mathrm{kN} / \mathrm{m}^{2}$ were applied on the floor, roof, and ceiling, respectively. Live loads were $1.9 \mathrm{kN} / \mathrm{m}^{2}$ for individual rooms and $4.8 \mathrm{kN} / \mathrm{m}^{2}$ for corridors. Snow load was $1.0 \mathrm{kN} / \mathrm{m}^{2}$.

Figure 2 shows a typical plan and an elevation of the MSBF. Each floor of the MSB consists of six modular units, which are connected horizontally. Lateral forces are resisted by external braced frames, as shown in Figure 2. The lateral response of the MSB in the N-S direction is considered in the study. Floor and ceiling beams were W250×33 and W100×19, respectively. Sections for the column and braces are given in Table 1. 
Table 1: section properties of the MSBF

\begin{tabular}{|l|c|c|}
\hline Storey & Column Sections & Area of Brace Core $\left(\mathrm{mm}^{2}\right)$ \\
\hline Storey 6 & HS $102 \times 102 \times 6$ & 1200 \\
\hline Storey 5 & HS $178 \times 178 \times 6$ & 2100 \\
\hline Storey 4 & HS $203 \times 203 \times 10$ & 2100 \\
\hline Storey3 & HS $305 \times 305 \times 10$ & 2100 \\
\hline Storey 2 & HS $305 \times 305 \times 13$ & 2100 \\
\hline Storey 1 & HS $305 \times 305 \times 13$ & 2100 \\
\hline
\end{tabular}
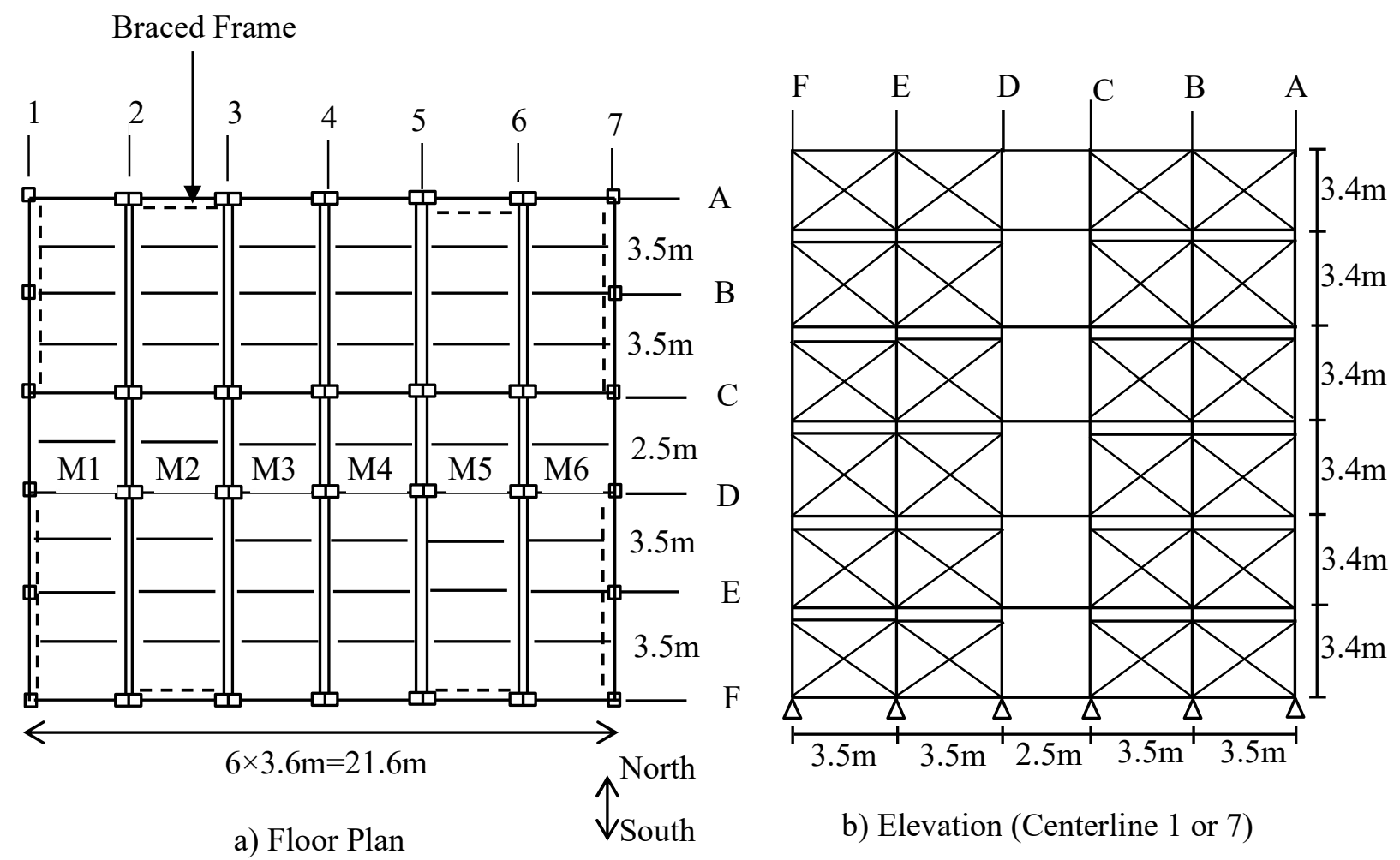

Figure 2: Six-storey modular steel braced frames 


\subsection{FINITE ELEMENT MODELING OF MSBF}

A nonlinear two-dimensional (2D) model was developed using the software SeismoStruct [21], which is based on the fibre element approach. The beams and columns were modelled using forcebased inelastic frame elements. The distributed dead load and $25 \%$ of the live load were considered

to calculate the seismic mass. The mass of each floor was then converted to lumped masses and applied at two ends of each beam. The analysis accounted for the P- $\Delta$ effect. Careful attention was made to the unique detailing of the MSB. Specific modeling assumptions are given below:

1) As beams and columns were assumed to be connected by direct welding, rigid beam-tocolumn connections were utilized.

2) The modules were assumed to be connected vertically by field welding at the outer faces of the columns since the inner faces of the columns were not accessible. This connection allows independent rotations of the upper and lower modules. Thus, the vertical joint between the modules was simulated as a pin connection to account for this behaviour [1].

3) The steel braces and the SMA braces of the MSBF were modelled using inelastic truss elements. Buckling behaviour was not modelled as braces were assumed to be buckling restrained.

4) Buckling of column was not explicitly modelled. Column capacity was determined according to FEMA 356 [23] considering the combined effect of axial and flexural load. It was verified that there was no stability problems.

Menegotto-Pinto [22] hysteretic material model with a yield stress $350 \mathrm{~N} / \mathrm{mm}^{2}$, an elastic modulus of $200 \mathrm{kN} / \mathrm{mm}^{2}$ and 3\% strain hardening [23] is assumed for the steel elements. The material model adopted an isotropic hardening rule. The SMA material model proposed by Aurichio [24] and 
implemented by Fugaza [25] was adopted in this study. The model assumes a constant stiffness for both the fully austenitic and fully martensitic behavior. The SMA material properties, provided in Table 2, were adopted from the study conducted by DesRoches et al. [26]. Figure 3 shows stressstrain parameters used to model superelastic SMA.

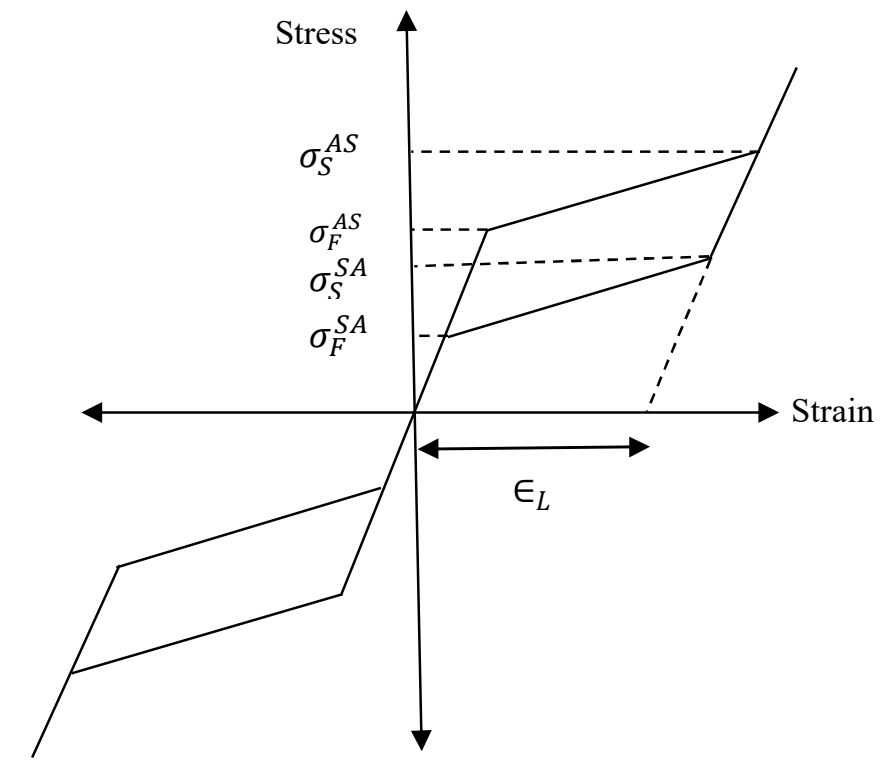

Figure 3: Stress-Strain parameter to model superelastic SMA

Table 2: Material properties of SMA

\begin{tabular}{|l|c|}
\hline Modulus of elasticity, ESMA & $55000 \mathrm{MPa}$ \\
\hline Austenite -to-martensite starting stress $\left(\sigma_{S}^{A S}\right)$ & $420 \mathrm{MPa}$ \\
\hline Austenite -to-martensite finishing stress $\left(\sigma_{F}^{A S}\right)$ & $520 \mathrm{MPa}$ \\
\hline Martensite-to-austenite starting stress $\left(\sigma_{S}^{S A}\right)$ & $310 \mathrm{MPa}$ \\
\hline Martensite-to-austenite finishing stress $\left(\sigma_{F}^{S A}\right)$ & $240 \mathrm{MPa}$ \\
\hline Superelastic plateau strain length $\left(\epsilon_{L}\right)$ & $6 \%$ \\
\hline
\end{tabular}




\subsection{Validation of FE modeling technique}

A concentrically braced steel frame tested by Wakabayashi et al. [27] was modelled using the technique explained in the previous section. Braces were modelled using inelastic frame elements. Buckling of the braces was modeled by assuming an initial geometric imperfection at their middle point with an amplitude of $1 \%$ of their length [28-29]. As the experimental cyclic load was not available, the cyclic load for numerical simulation was developed based on the experimental maximum storey displacement, shown in the Figure 4(a). The numerical and experimental results are shown in Figure 4. The FE model provided reasonable predictions of the frame behaviour in terms of maximum base shear and maximum storey displacement.

Annan et al. [2] experimentally assessed the hysteretic characteristics of a MSBF, Figure 5. The frame was modelled using the described modeling technique. Figure 6 shows details of the model. The rigid connections between beams and columns were modelled using rigid elements as presented with heavy lines. Member M1 represents the $150 \mathrm{~mm}$ vertical clearance required for fire proofing between any two storeys. The vertical joint, $\mathrm{j} 5$, was simulated using a pin connection to allow independent rotation of upper and lower modules. Figure 7 compares the experimental and analytical results. The maximum base shear obtained from FE analysis is lower than that obtained experimentally by $6.67 \%$. The model was also able to accurately capture the energy dissipation characteristics and the residual drift values. 

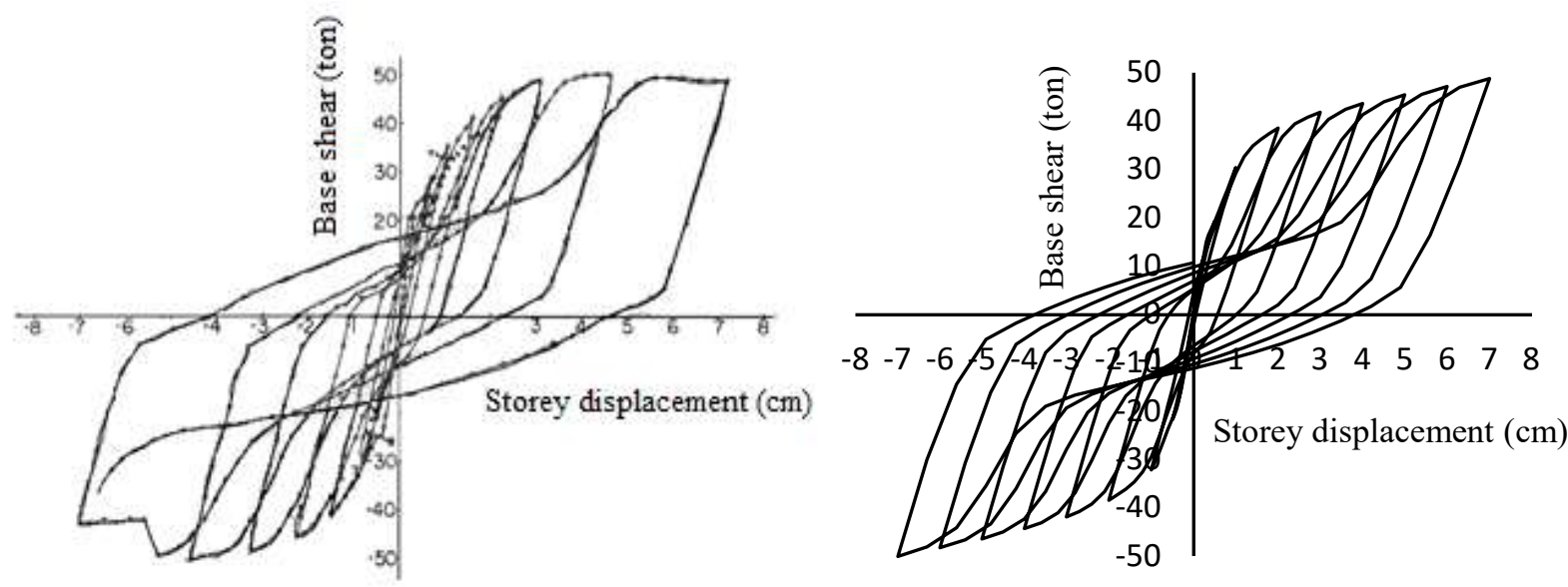

a) Experimental result [27]

b) Numerical simulation

Figure 4: Comparison of numerical and experimental responses

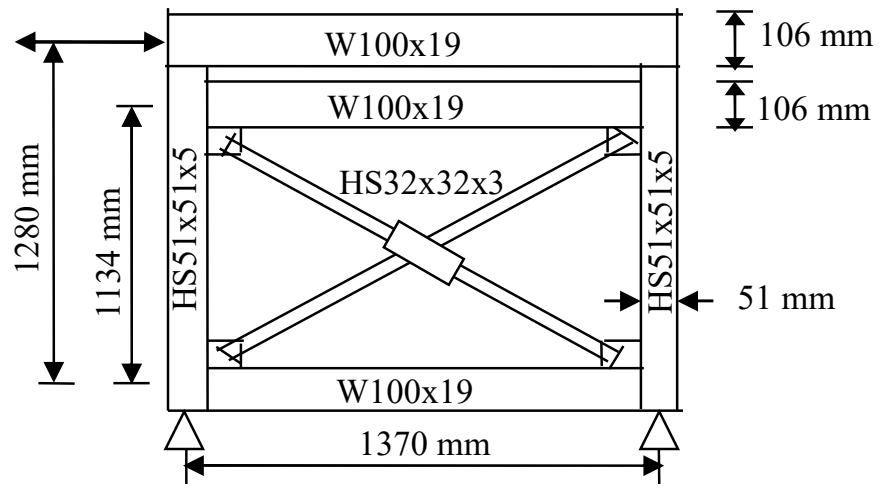

Figure 5: Geometry of MSBF tested by Annan et al. [2] 


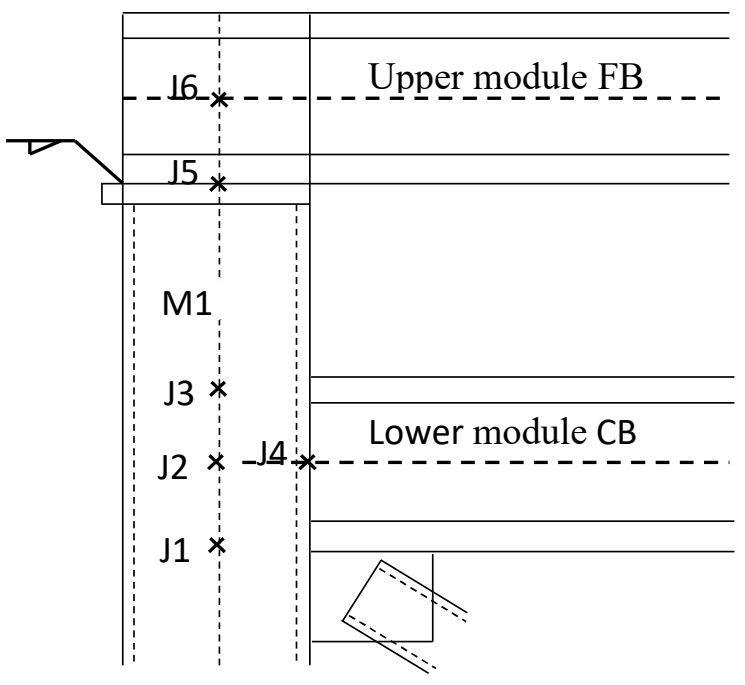

Vertical connection representation

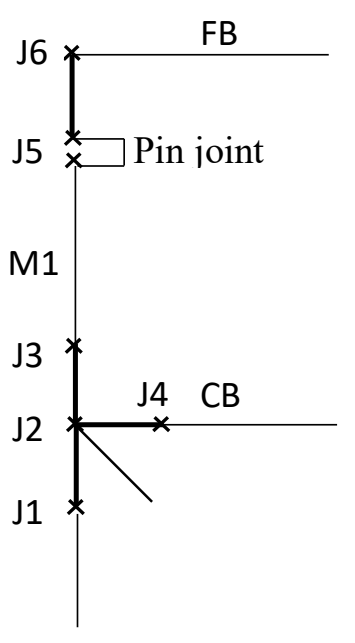

Model representation

Figure 6: Model of vertical connection of MSBF

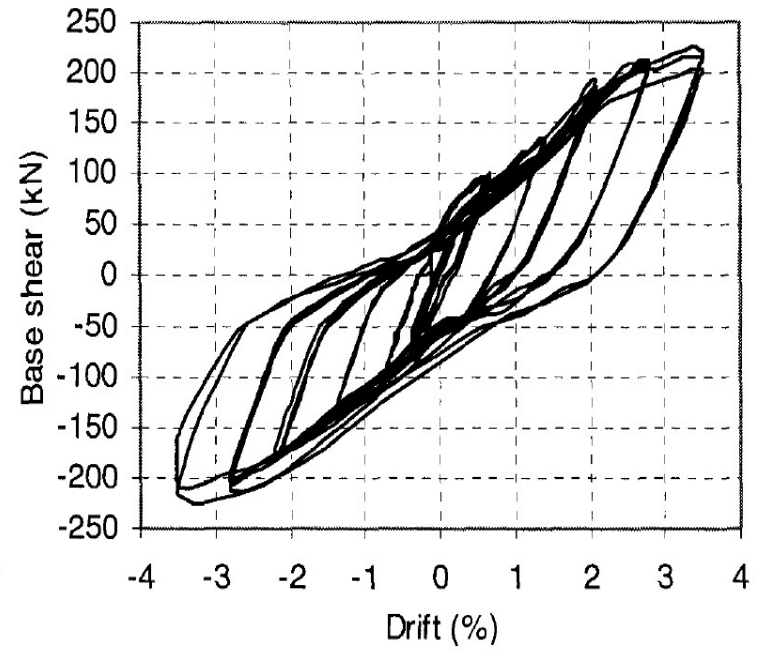

a) Experimental [2]

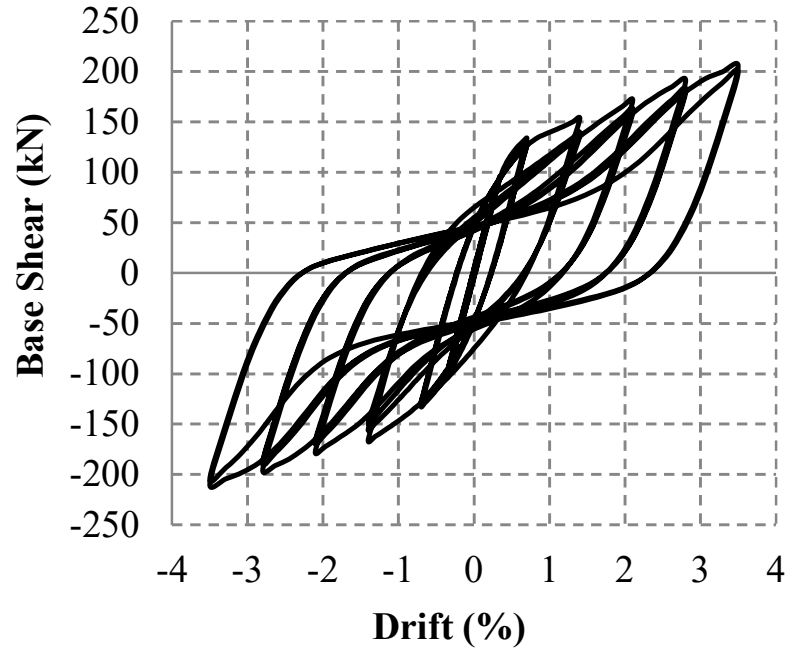

b) Numerical simulation

Figure 7: Comparison of experimental and numerical results 


\subsection{DYNAMIC ANALYSIS OF STEEL-MSBF (FRAME 1)}

The seismic performance of structures is highly influenced by the frequency content, duration and intensity of the ground motions. Five different ground motions that cover these variables were selected from PEER ground motion database [30] based on the elastic response spectra for 5\% damping, which show maximum responses between first and second mode of vibrations. Their characteristics are listed in Table 3. Figure 8 shows the elastic response spectra of the selected ground motions considering 5\% damping.

Eigen value analysis was performed to determine the natural period of vibrations and mode shapes of the six-storey steel-MSBF (Frame 1). The first and second natural periods of vibrations were 0.54 second and 0.19 second, respectively. Incremental dynamic analyses (IDA) were performed by scaling the ground motions to different intensities. 5\% Rayleigh damping was considered for the numerical model. Damping of the SMA was obtained through material nonlinearity. The seismic intensity is expressed in term of the spectral acceleration at the first period of vibration [Sa(T1, 5\%)]. MID and MRID were selected as global demand parameters of the selected frames.

Table 3: Characteristics of the ground motions

\begin{tabular}{|l|c|c|l|c|}
\hline Earthquake & Year & $\begin{array}{c}\text { Ms } \\
\text { magnitude }\end{array}$ & \multicolumn{1}{|c|}{ Station } & PGA(g) \\
\hline Imperial Valley & 1979 & 6.9 & El Centro Array \#13 & 0.139 \\
\hline Northridge & 1994 & 6.7 & Arleta-Nordhoff & 0.344 \\
\hline Superstition Hills-02 & 1987 & 6.54 & Parachute Test Site & 0.432 \\
\hline Loma Prieta & 1989 & 7.1 & Capitola & 0.451 \\
\hline Tabas & 1978 & 6.9 & Tabas & 0.852 \\
\hline
\end{tabular}




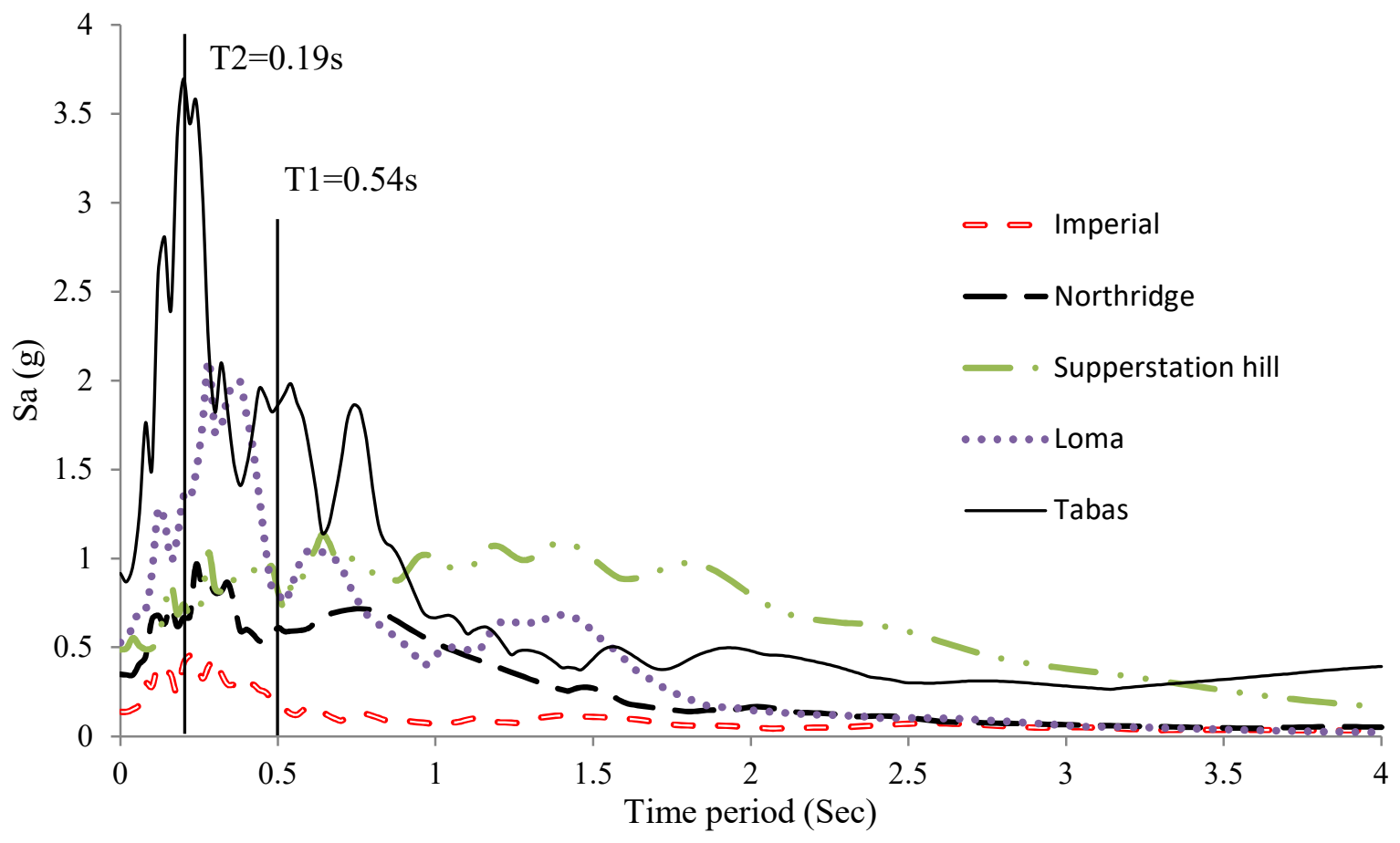

Figure 8: Elastic response spectra

The failure criteria of frame members are determined based on FEMA 356 [23]. The momentrotation behaviour of the frame members is shown in Figure 9. The parameter "a" defines the plastic rotation at ultimate condition. Values for this parameter are given in Table 4. The ultimate rotation $\left(\theta_{\mathrm{u}}\right)$ can be obtained by adding the plastic rotation to the yield rotation. Local failure of beams and columns with axial force ratio, $\mathrm{P} / \mathrm{P}_{\mathrm{CL}} \leq 0.5$, are associated with an ultimate chord rotation $\left(\theta_{\mathrm{u}}\right)$ [23]. For column axial force ratio, $\mathrm{P} / \mathrm{P}_{\mathrm{CL}} \geq 0.5$, failure is based on equation 1 [23]. Collapse was defined when four columns of any storey reach failure.

$\frac{P_{U F}}{P_{C L}}+\frac{M u_{F x}}{M_{C L X}}+\frac{M u_{F y}}{M_{C L y}} \leq 1$ 


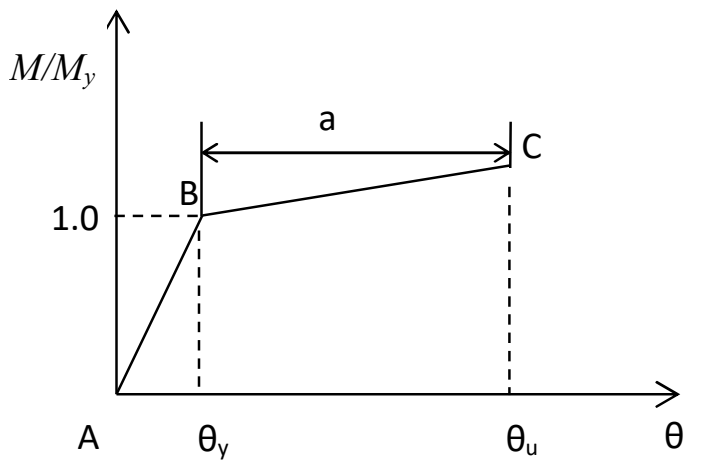

Figure 9: Moment-rotation behaviour for steel elements [23]

Table 4: Modeling parameters for nonlinear procedures according to FEMA356 [23].

\begin{tabular}{|c|c|}
\hline Component & $\begin{array}{c}\text { Plastic rotation } \\
\text { angle (radians) } \\
\text { a }\end{array}$ \\
\hline $\begin{array}{c}\text { Beam } \\
\text { a. } \frac{b_{f}}{2 t_{f}} \leq \frac{52}{\sqrt{F_{y e}}} \text { and } \frac{h}{t_{w}} \leq \frac{418}{\sqrt{F_{y e}}}\end{array}$ & $9 \theta_{y}$ \\
b. $\frac{b_{f}}{2 t_{f}} \geq \frac{65}{\sqrt{F_{y e}}}$ or $\frac{h}{t_{w}} \geq \frac{640}{\sqrt{F_{y e}}}$ & $4 \theta_{y}$ \\
Column & \\
For $P / P_{c l}<0.2$ & \\
a. $\frac{b_{f}}{2 t_{f}} \leq \frac{52}{\sqrt{F_{y e}}}$ and $\frac{h}{t_{w}} \leq \frac{300}{\sqrt{F_{y e}}}$ & $9 \theta_{y}$ \\
b. $\frac{b_{f}}{2 t_{f}} \geq \frac{65}{\sqrt{F_{y e}}}$ or $\frac{h}{t_{w}} \geq \frac{460}{\sqrt{F_{y e}}}$ & $4 \theta_{y}$ \\
Column & \\
For $0.2 \leq P / P_{c l} \leq 0.5$ & $11\left(1-1.7 P / P_{C L}\right) \theta_{y}$ \\
a. $\frac{b_{f}}{2 t_{f}} \leq \frac{52}{\sqrt{F_{y e}}}$ and $\frac{h}{t_{w}} \leq \frac{260}{\sqrt{F_{y e}}}$ & $1 \theta_{y}$ \\
b. $\frac{b_{f}}{2 t_{f}} \geq \frac{65}{\sqrt{F_{y e}}}$ or $\frac{h}{t_{w}} \geq \frac{400}{\sqrt{F_{y e}}}$ & $11 \Delta_{T}$ \\
Braces &
\end{tabular}




\subsection{Results for Frame 1}

The intensity $\left[\mathrm{S}_{\mathrm{a}}(\mathrm{T} 1,5 \%)\right]$ at which Frame 1 failed as well as the corresponding MID and MRID are listed in Table 5. Values of the MID varied from 3.24\% to $4.21 \%$ and occurred at the first storey. The MRID varied from $0.32 \%$ to $0.62 \%$. The storey experiencing the MID was generally different than that experiencing the MRID with the exception of Tabas earthquake. Figure 10 shows the distribution of ID and RID along the building height at collapse. It is observed that first three storeys experienced higher IDs and RIDs as compared to the top three storeys.

Table 5: MID and MRID of Frame 1 at collapse

\begin{tabular}{|l|c|c|c|}
\hline \multirow{2}{*}{ Ground motion } & \multirow{2}{*}{$\begin{array}{c}\text { Sa(T1,5\%) } \\
\text { at collapse }\end{array}$} & MID (\%) & MRID (\%) \\
\cline { 3 - 4 } & $3.84 \mathrm{~g}$ & $3.37\left(1^{\text {st }}\right.$ storey $)$ & $0.57\left(2^{\text {nd }}\right.$ storey $)$ \\
\hline Imperial & $2.81 \mathrm{~g}$ & $3.42\left(1^{\text {st }}\right.$ storey $)$ & $0.58\left(2^{\text {nd }}\right.$ storey $)$ \\
\hline Northridge & $3.36 \mathrm{~g}$ & $4.21\left(1^{\text {st }}\right.$ storey $)$ & $0.62\left(3^{\text {rd }}\right.$ storey $)$ \\
\hline Superstition Hills & $3.95 \mathrm{~g}$ & $3.33\left(1^{\text {st }}\right.$ storey $)$ & $0.32\left(2^{\text {nd }}\right.$ storey $)$ \\
\hline Loma & $5.95 \mathrm{~g}$ & $3.24\left(1^{\text {st }}\right.$ storey $)$ & $0.47\left(1^{\text {st }}\right.$ storey $)$ \\
\hline Tabas &
\end{tabular}




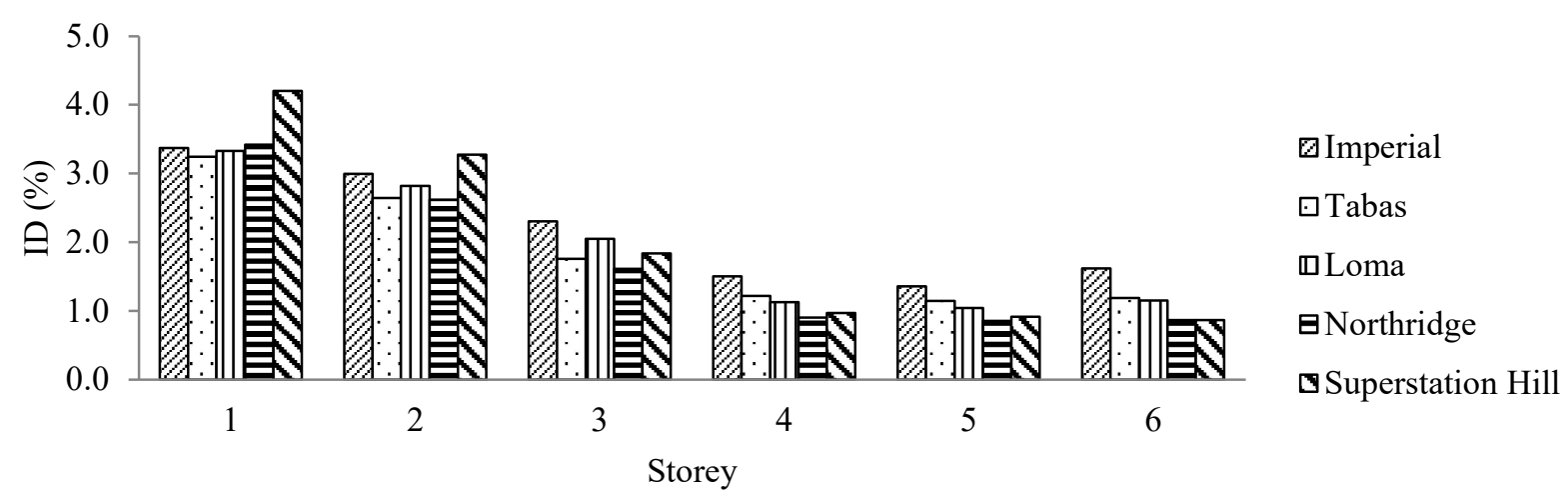

a) ID

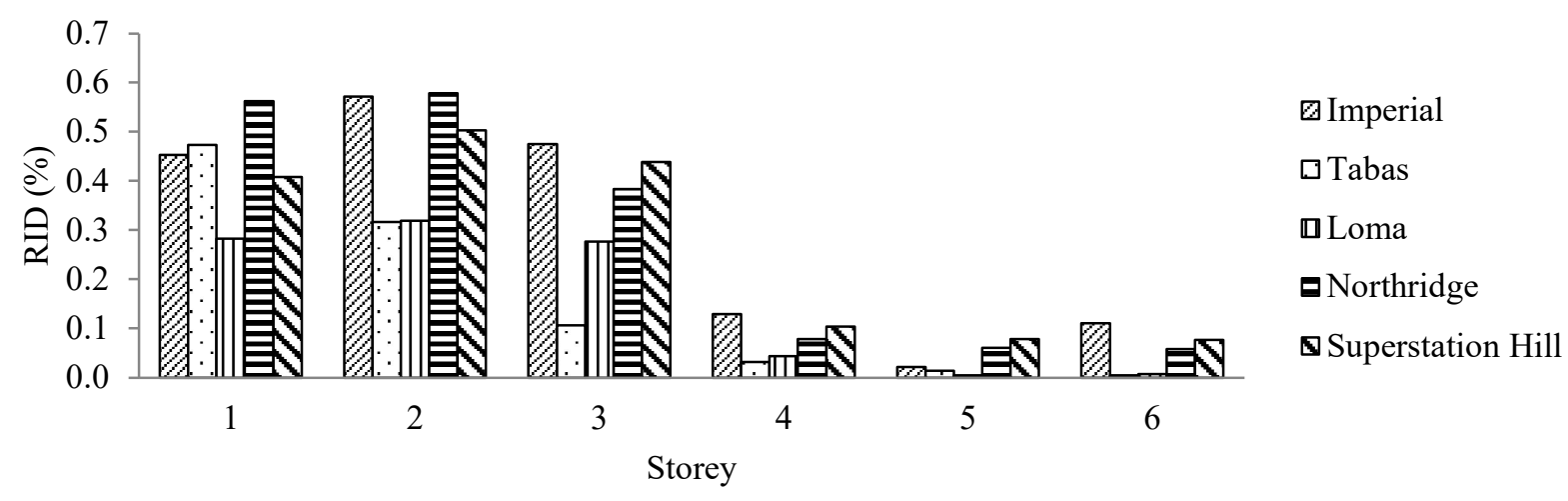

b) RID

Figure 10: ID and RID distribution for Frame 1 at collapse

Figure 11 shows the damage distribution of Frame 1 at collapse. Yielding of columns and beams are shown by solid black dots and yielding of braces is represented by heavy lines. Beams in the unbraced bays as well as floor and ceiling beams of the $1^{\text {st }}$ and $2^{\text {nd }}$ storeys yielded considering all records. Yielding of ceiling beams at other stories was also observed. Braces of the bottom storeys were severely damaged whereas some braces of the top two storeys remained elastic. Yielding of columns is observed at different storeys. Failure mode was soft first storey of the frame. The exterior columns and the columns of the unbraced bays experienced more damage than the remaining columns. All of the interior columns of the unbraced bays failed during Imperial, Loma and Tabas earthquakes. 
The ID and RID distributions along the frame height, shown in Figure 10, agree with the observed damage distribution. Also, yielding of short columns between the modules that was observed agrees with the experimental results conducted by Annan et al. [2]. The welds in these locations were checked and found to be safe considering the seismic demands. Same conclusion was reached by Annan et al. [1-2].The yield distribution of the Frame 1 suggests good distribution of energy dissipation along the height and width of the modular braced frame.

\subsection{SMA-MSBFs CHARACTERISTICS AND MODELING}

Locations of the SMA braces were based on the damage distribution observed in Frame 1. Five different configurations for the SMA braces were selected as shown in Figure 12. Cross section and length of the SMA elements in the BR-SMA braces were determined using Equations 2 and 3 to obtain the same yielding strength, $\mathrm{F}_{\mathrm{y}}$, and axial stiffness, $\mathrm{K}$, as BR-Steel braces. As a result, the BR-SMA braced frames had the same natural period as Frame 1.

$$
\begin{aligned}
& A^{S M A}=\frac{F_{y}}{\sigma_{S}^{A S}}=\frac{350 \times A^{S T E E L}}{420}=0.83 \times A^{S T E E L} \\
& L^{S M A}=\frac{E^{S M A} \times A^{S M A}}{K}=\frac{55000 \times 0.83 A^{S T E E L}}{2 e 5 \times A^{S T E E L}} \times L^{S T E E L}=0.23 L^{S T E E L}
\end{aligned}
$$

Table 6 shows the required length and cross section area of SMA braces. Rigid elements were used with the SMA truss element to make sure that all the deformations would happen in the SMA segments of braces. Similar design philosophy was used by other researchers [9, 15-17]. SMA braces were modelled using inelastic truss elements that were connected to rigid elements as shown in Figure 13. The same beam and column sizes of Frame 1 were maintained in the SMA-MSBF. 


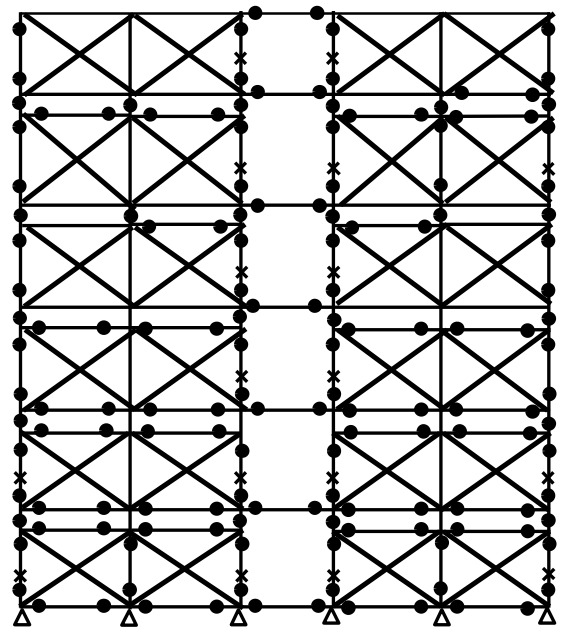

a) Imperial, $\mathrm{Sa}(\mathrm{T} 1,5 \%)=3.84 \mathrm{~g}$

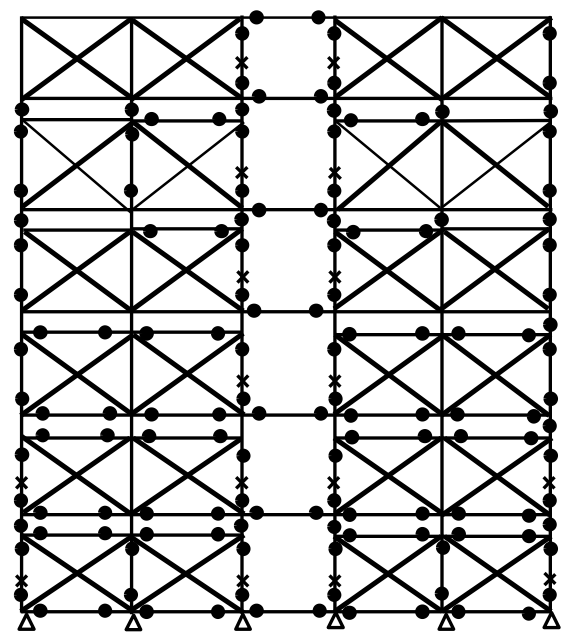

c) Loma, Sa $(\mathrm{T} 1,5 \%)=3.95 \mathrm{~g}$

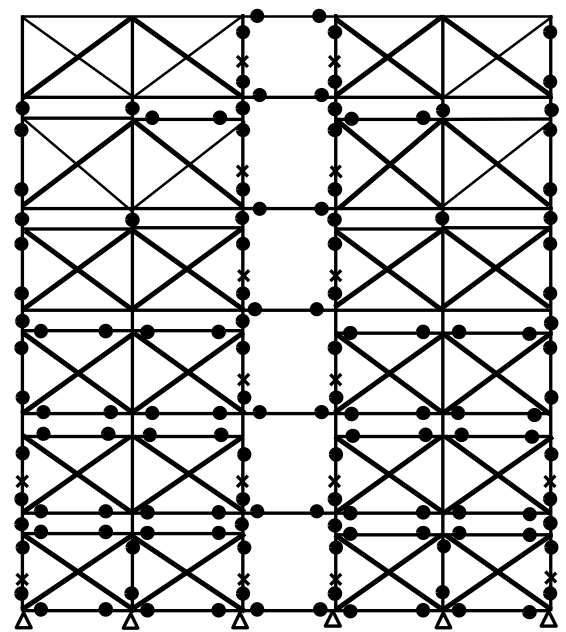

b) Tabas, $\mathrm{Sa}(\mathrm{T} 1,5 \%)=5.95 \mathrm{~g}$

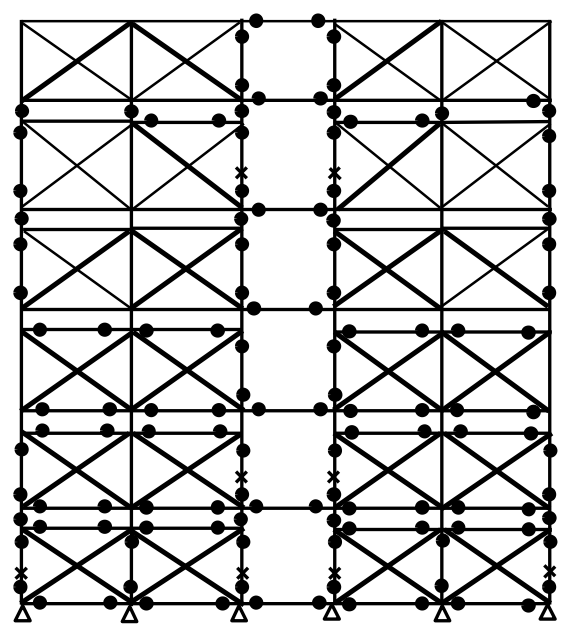

d) Northridge, $\mathrm{Sa}(\mathrm{T} 1,5 \%)=2.81 \mathrm{~g}$

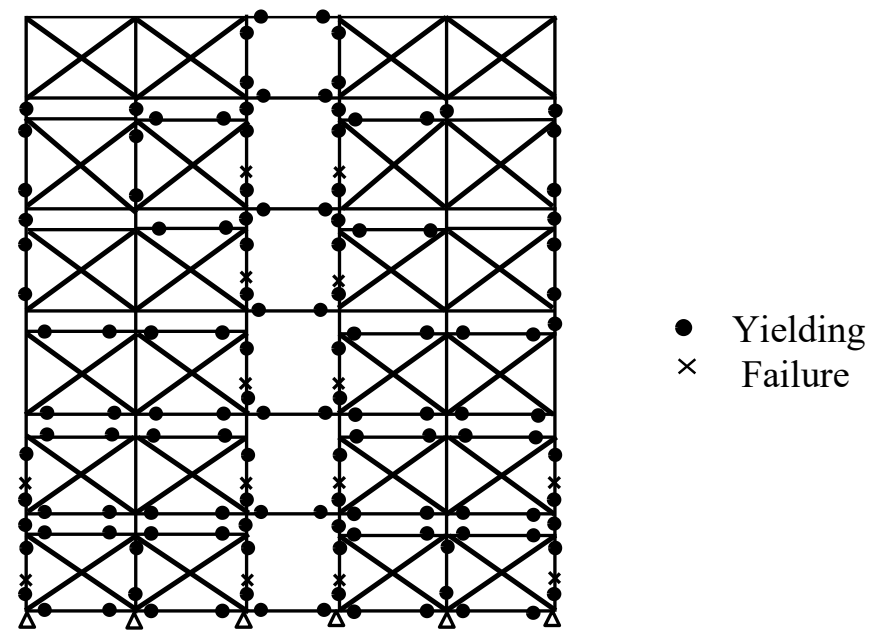

e) Superstition Hills, $\mathrm{Sa}(\mathrm{T} 1,5 \%)=3.36 \mathrm{~g}$

Figure 11: Damage distribution of Frame 1 at collapse 


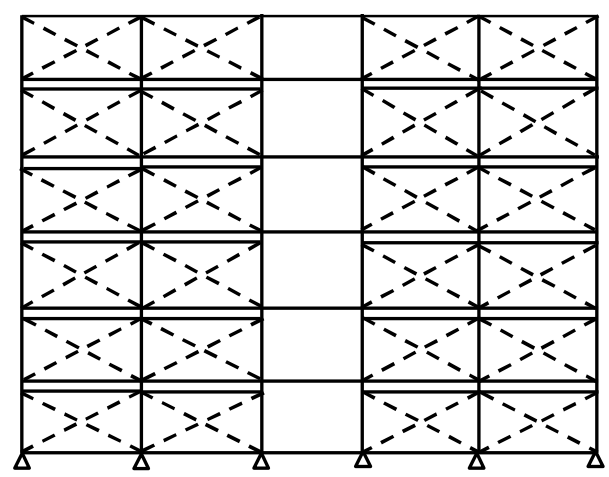

Frame 2

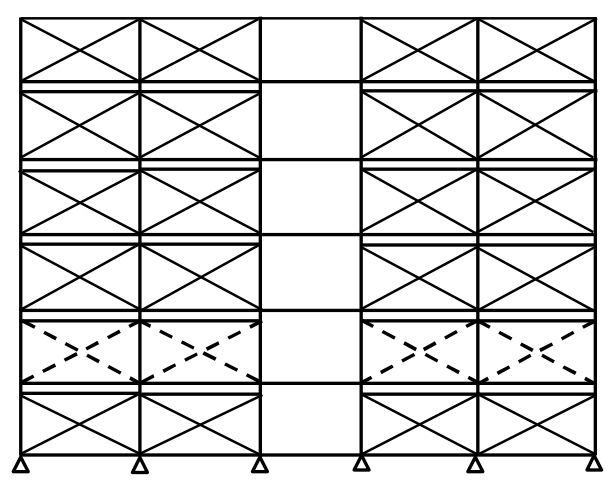

Frame 4

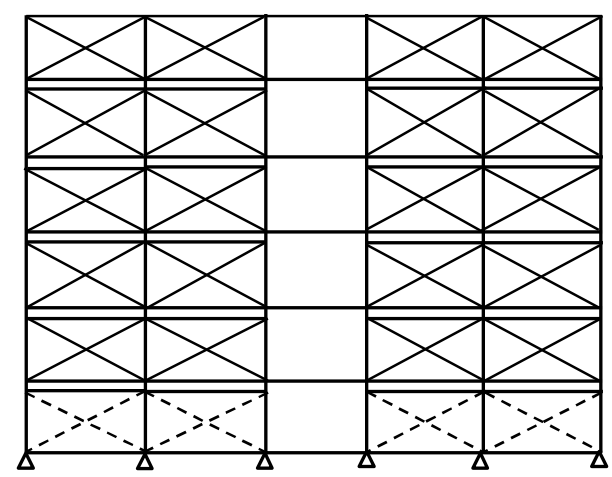

Frame 3

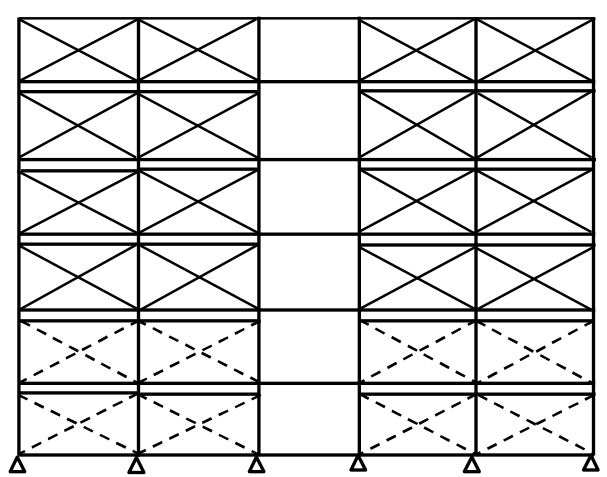

Frame 5

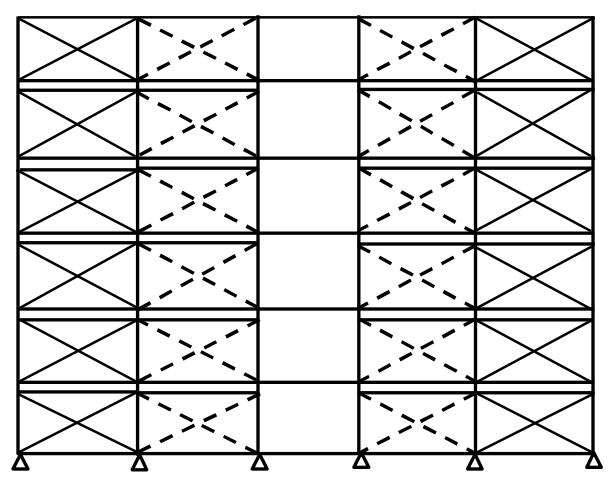

Frame 6

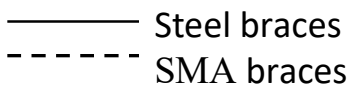

Figure 12: SMA braced frames 
Table 6: Geometrical characteristic of SMA braces

\begin{tabular}{|c|c|c|}
\hline Storey & $\begin{array}{c}\text { SMA braces length } \\
(\mathrm{mm})\end{array}$ & $\begin{array}{c}\text { SMA braces area } \\
\left(\mathrm{mm}^{2}\right)\end{array}$ \\
\hline 1 & 548.0 & 1958.0 \\
\hline 2 & 558.0 & 1958.0 \\
\hline 3 & 558.0 & 1958.0 \\
\hline 4 & 558.0 & 1958.0 \\
\hline 5 & 558.0 & 1958.0 \\
\hline 6 & 585.0 & 1207.0 \\
\hline
\end{tabular}

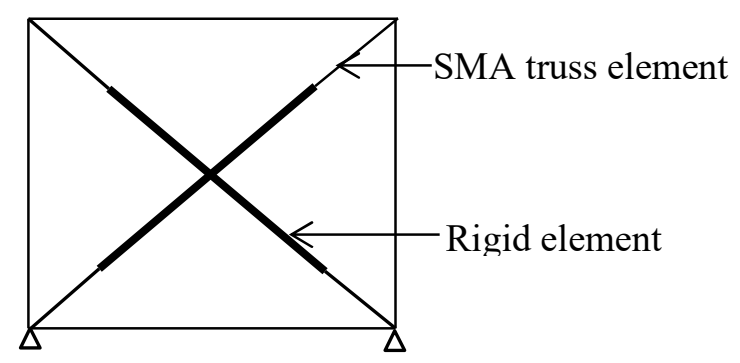

Figure 13: Braced bay of SMA-MSBF

\subsection{RESULTS FOR SMA-MSBFs}

Dynamic analyses of the SMA-MSBFs were performed considering the same intensities at which Frame 1 collapsed. Figure 14 compares the MID and MRID distributions for the analyzed frames. It is observed that the MID and MRID of the SMA frames varied from 3.18\% to $4.24 \%$ and $0.005 \%$ to $0.62 \%$, respectively. Table 7 shows the percentage change of MID and MRID as compared with Frame 1. 
The MID depended on the locations of SMA braces and the characteristics of the considered ground motion. For example, replacing all braces by SMA braces (Frame 2) increased the MID considering imperial, Tabas, Loma and Northridge records up to $8.77 \%$ but reduced its value considering Superstition Hills record by 7.98\%. Although the same numbers of SMA braces were used in Frames 3 and 4, the MID decreased in Frame 4 but increased in Frame 3 as compared to Frame 1 for Imperial, Loma and Northridge earthquakes. The slight increase or decrease in the MID values does not provide basis to choose a specific SMA configuration.

The highest reduction of the MRID occurred in Frame 2 reaching up to 98.6\%. For Frame 3, the MRID increased in case of Superstition Hill record as compared to Frame 1, which clearly shows that using SMA at the wrong locations might worsen the seismic performance. For SMA frames 4 and 5, the percentage reduction of MRID varied from $4.31 \%$ to $40.2 \%$ and $18.71 \%$ to $87.9 \%$, respectively. Frame 6 showed better seismic performance than Frames 3, 4 and 5 as its MID slightly increased (8.3\%) but the frame regained $63.5 \%$ to $84.93 \%$ of its MRID.

Figures 15 to 19 compare the IDs and RIDs of the different frames. The IDs for Frames 2 to 6 were very similar. However, the RIDs were significantly different. The SMA braces resulted in redistributing the seismic forces in the frame, and, thus, had significantly influenced the location of the storey experiencing the MRID. It is observed that using SMA braces only in the first storey (Frame 3) had significantly reduced the residual drifts of that storey. This reduction was not pronounced in other storeys. The same observation can be made for Frames 4 and 5. The highest reduction of RIDs occurred in Frame 2 followed by Frame 6, which indicated the necessity of using SMA braces along the building height to minimize the RID. 
Table 7 Percentage change of MID and MRID of SMA frames

\begin{tabular}{|c|c|c|c|c|c|c|c|c|c|c|}
\hline \multirow[b]{2}{*}{$\begin{array}{c}\text { Frame } \\
\text { type }\end{array}$} & \multicolumn{2}{|c|}{ Imperial } & \multicolumn{2}{|c|}{ Tabas } & \multicolumn{2}{|c|}{ Loma } & \multicolumn{2}{|c|}{ Northridge } & \multicolumn{2}{|c|}{ Superstition Hills } \\
\hline & $\begin{array}{c}\text { MID } \\
\% \\
\text { change }\end{array}$ & $\begin{array}{c}\text { MRID } \\
\% \\
\text { change }\end{array}$ & $\begin{array}{c}\text { MID } \\
\% \\
\text { Change }\end{array}$ & $\begin{array}{c}\text { MRID } \\
\% \\
\text { change }\end{array}$ & $\begin{array}{c}\text { MID } \\
\% \\
\text { Change }\end{array}$ & $\begin{array}{c}\text { MRID } \\
\% \\
\text { change }\end{array}$ & $\begin{array}{c}\text { MID } \\
\% \\
\text { Change }\end{array}$ & $\begin{array}{c}\text { MRID } \\
\% \\
\text { change }\end{array}$ & $\begin{array}{c}\text { MID } \\
\% \\
\text { Change }\end{array}$ & $\begin{array}{c}\text { MRID } \\
\% \\
\text { change }\end{array}$ \\
\hline Frame 2 & 8.77 & -79.7 & 8.04 & -86.5 & 1.63 & -98.6 & 5.08 & -88.1 & -7.98 & -81.1 \\
\hline Frame 3 & 2.89 & -22.8 & 4.85 & -13.7 & 0.83 & -40.4 & 5.76 & 6.9 & -8.42 & 7.8 \\
\hline Frame 4 & -2.12 & -24.4 & 0.34 & -4.31 & -4.45 & -31.6 & -0.08 & -9.9 & -8.42 & -40.2 \\
\hline Frame 5 & 5.89 & -30.9 & 4.17 & -48.7 & -1.53 & -87.5 & 5.52 & -54.5 & 0.76 & -18.8 \\
\hline Frame 6 & 2.76 & -74.7 & 8.30 & -84.9 & 2.39 & -81.6 & 5.79 & -65.9 & -9.74 & -63.5 \\
\hline
\end{tabular}

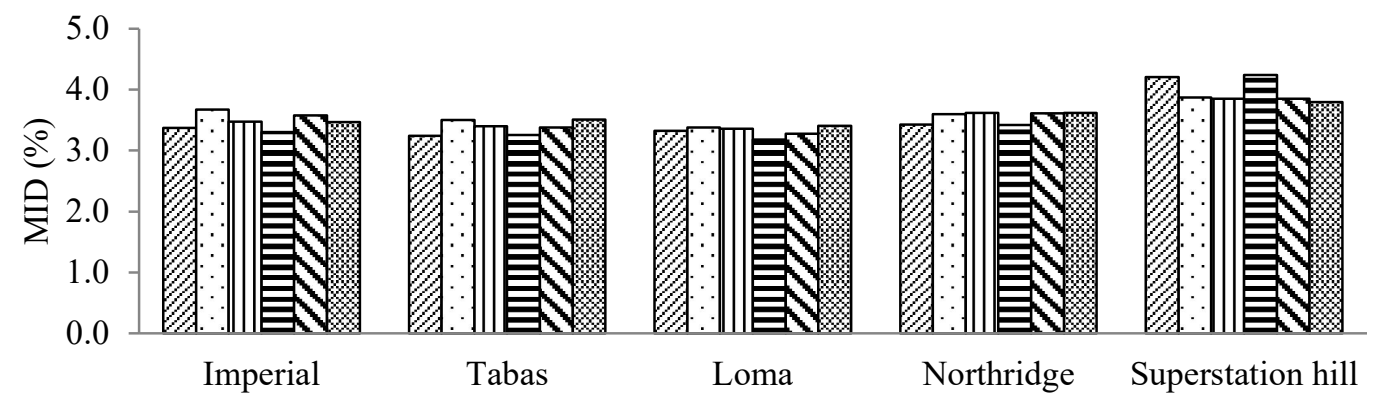

๑ Frame 1

口Frame 2

๓ Frame 3

EFrame 4

$\mathbf{D F r a m e} 5$

강 Frame 6

a) MID

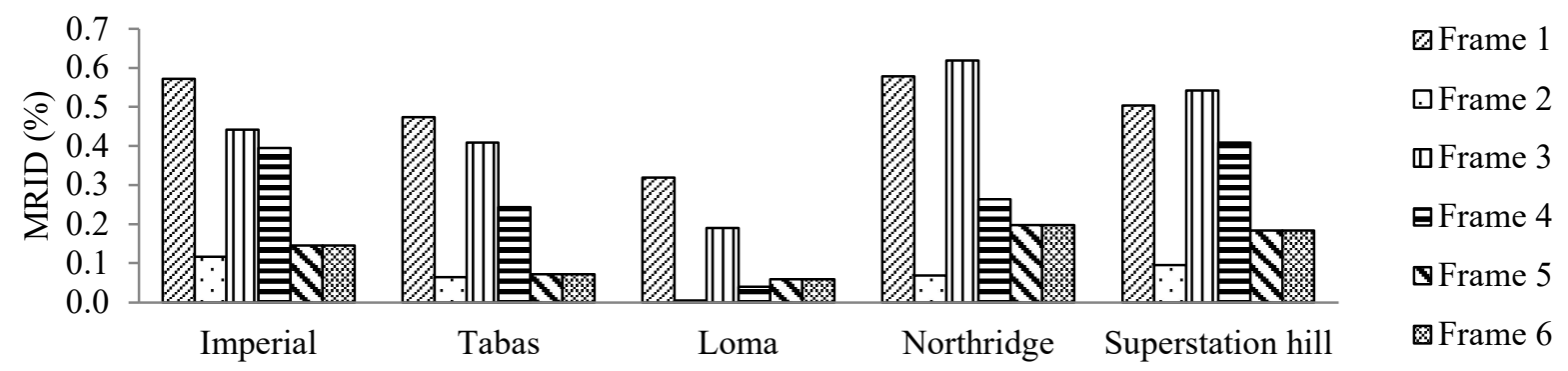

b) MRID

Figure 14: Drift values at intensity causing collapse to Frame 1 


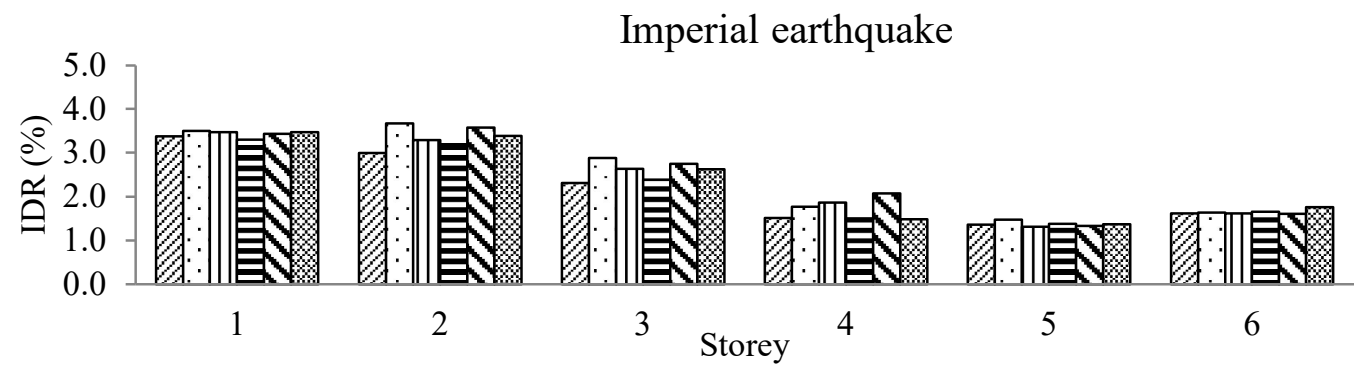

๑ Frame 1

QFrame 2

DFrame 3

日Frame 4

QFrame 5

图Frame 6

a) ID

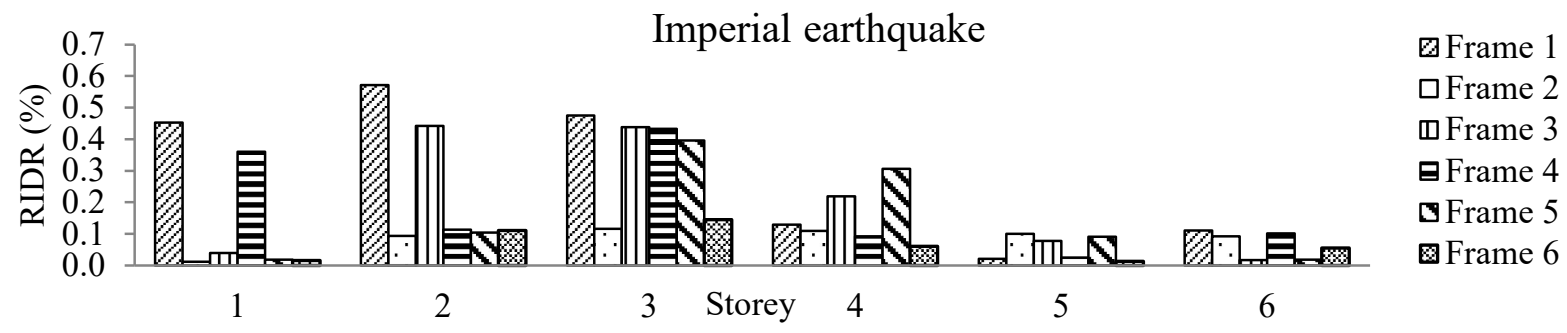

b) RID

Figure 15: Storey drifts for Imperial earthquake [Sa(T1, 5\%)=3.84g]

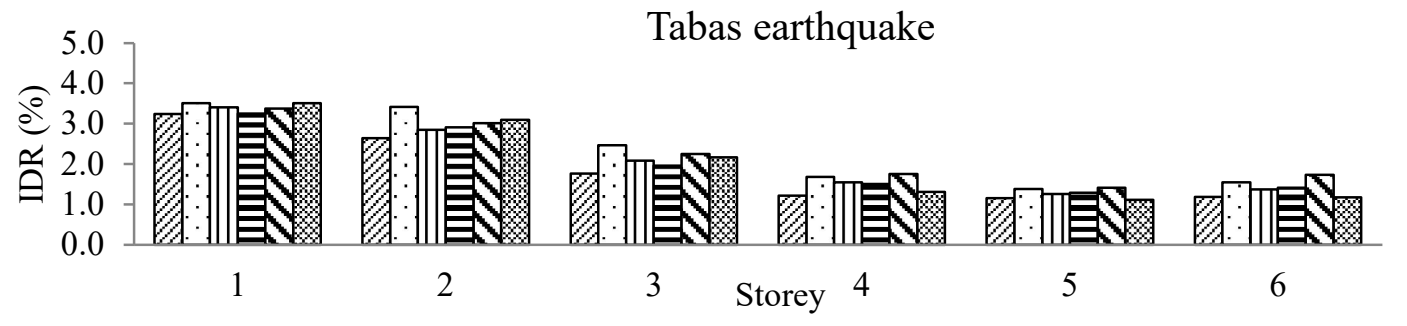

๑rame 1 口Frame 2 口Frame 3 EFrame 4 sFrame 5 圆Frame 6

a) ID

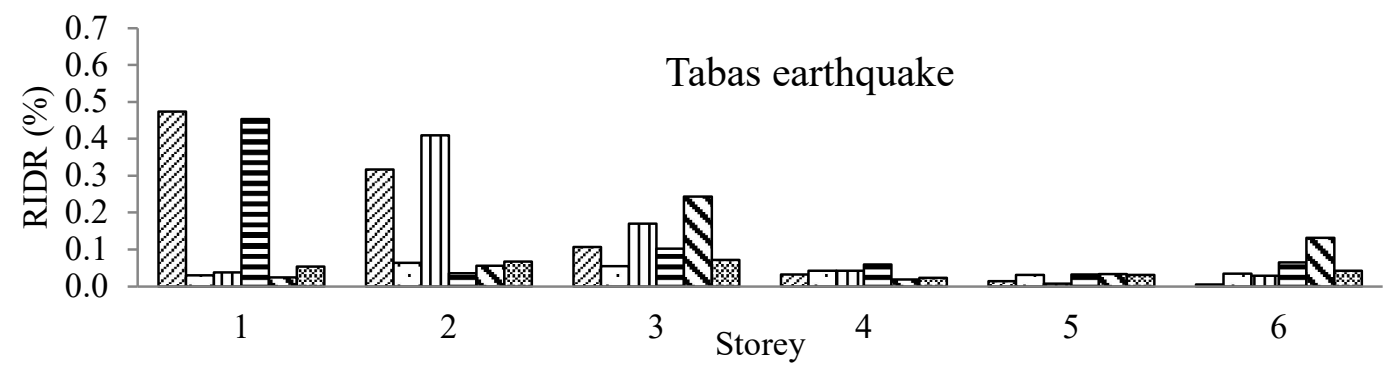

QFrame 1 $\square$ Frame 2 口Frame 3 EFrame 4 SFrame 5 冈rame 6

b) RID

Figure 16: Storey drifts for Tabas earthquake $[\mathrm{Sa}(\mathrm{T} 1,5 \%)=5.95 \mathrm{~g}]$ 


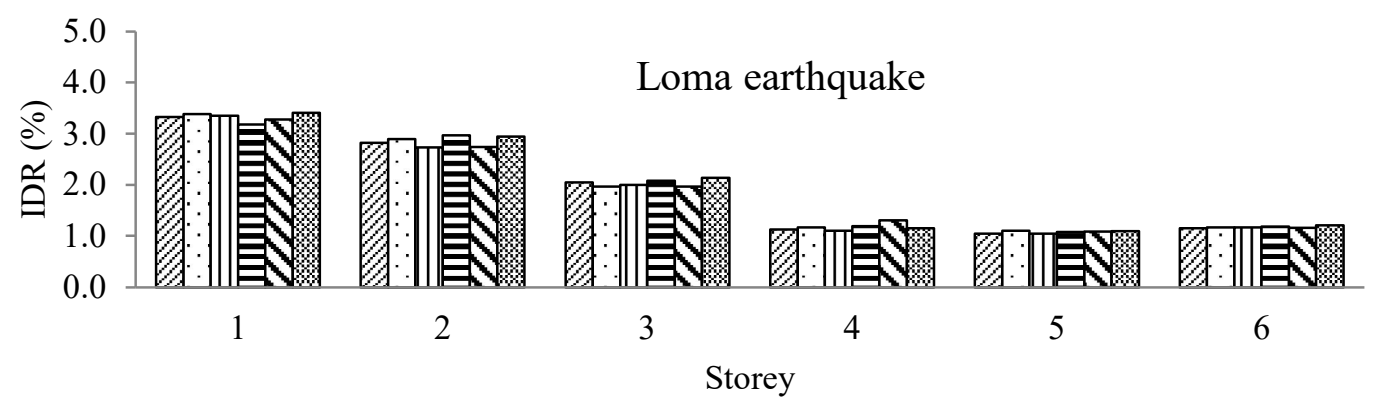

arame 1

$\square$ Frame 2

๑Frame 3

EFrame 4

QFrame 5

장 Frame 6

a) ID

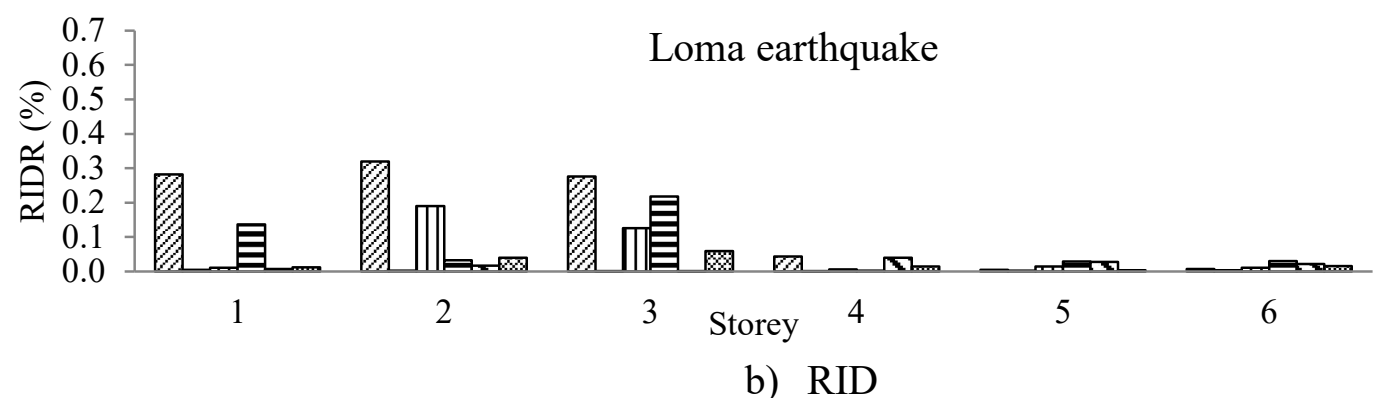

a Frame 1

口Frame 2

口Frame 3

日Frame 4

هFrame 5

맘 Frame 6

Figure 17: Storey drifts for Loma earthquake [Sa $(\mathrm{T} 1,5 \%)=3.95 \mathrm{~g}]$

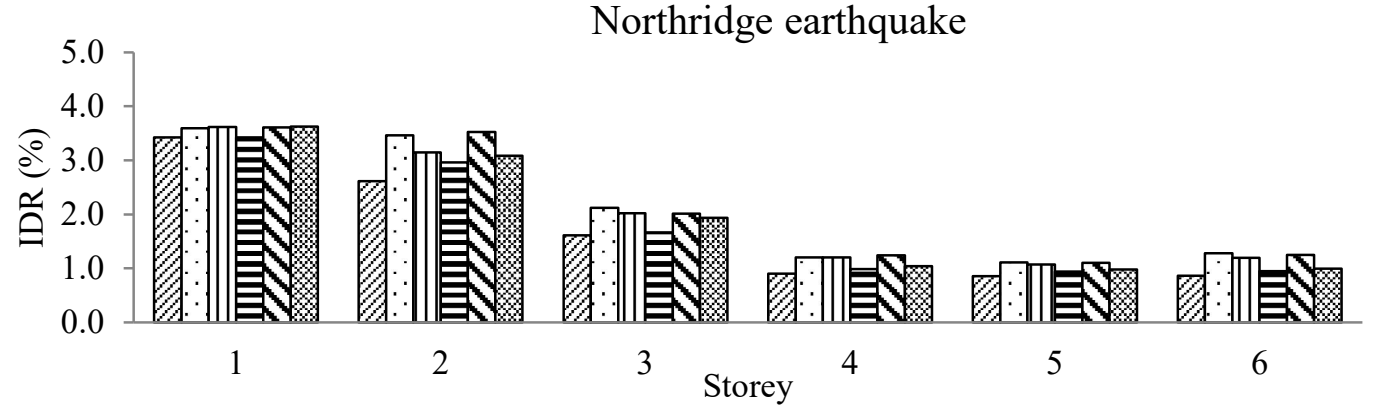

๑Frame 1

$\square$ Frame 2

๑Frame 3

EFrame 4

बFrame 5

图 Frame 6

a) ID

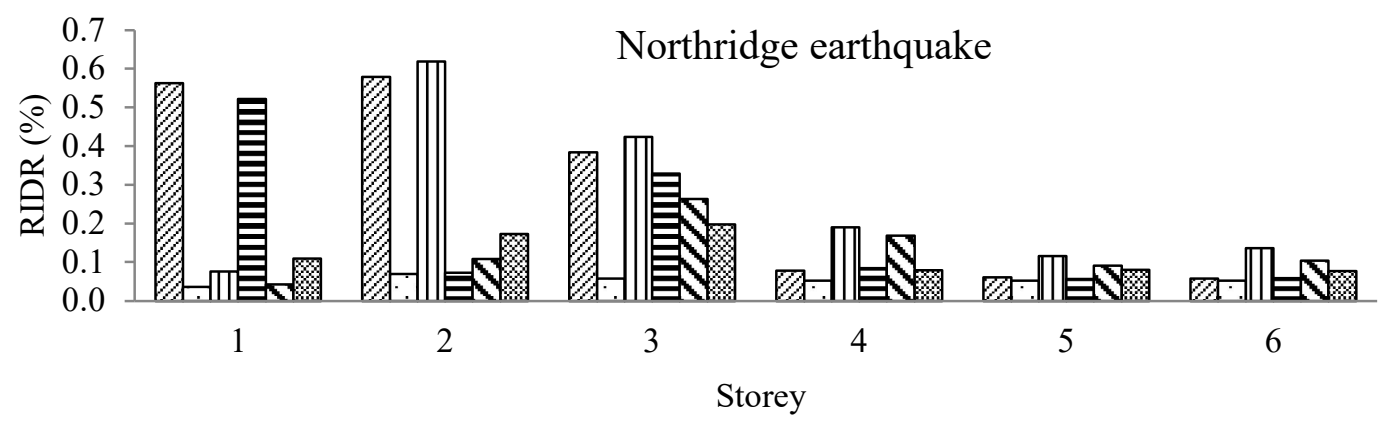

๑Frame 1

$\square$ Frame 2

aFrame 3

日Frame 4

QFrame 5

图Frame 6

b) RID

Figure 18: Storey drifts for Northridge earthquake [Sa $(\mathrm{T} 1,5 \%)=2.81 \mathrm{~g}]$ 


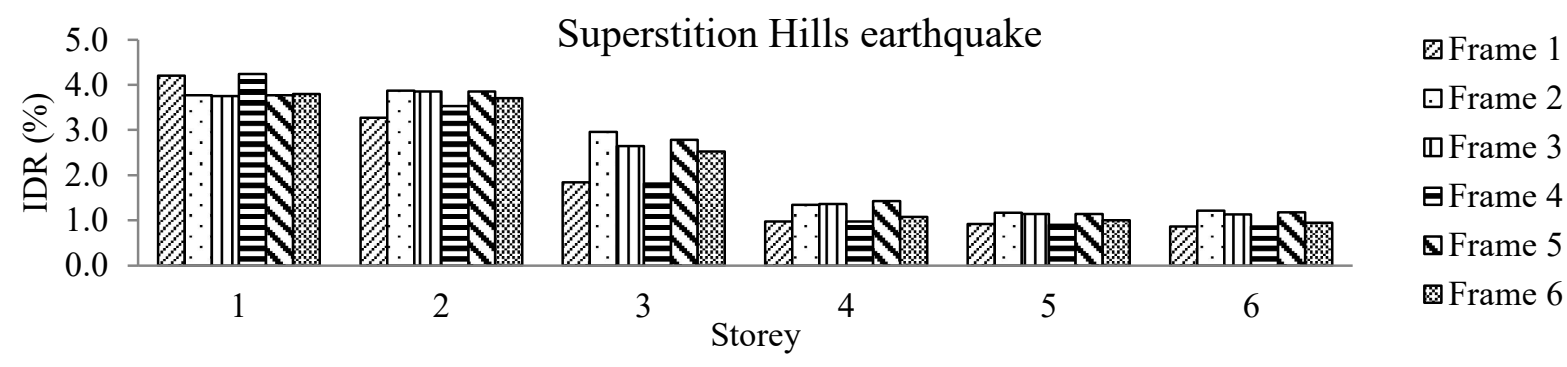

a) ID

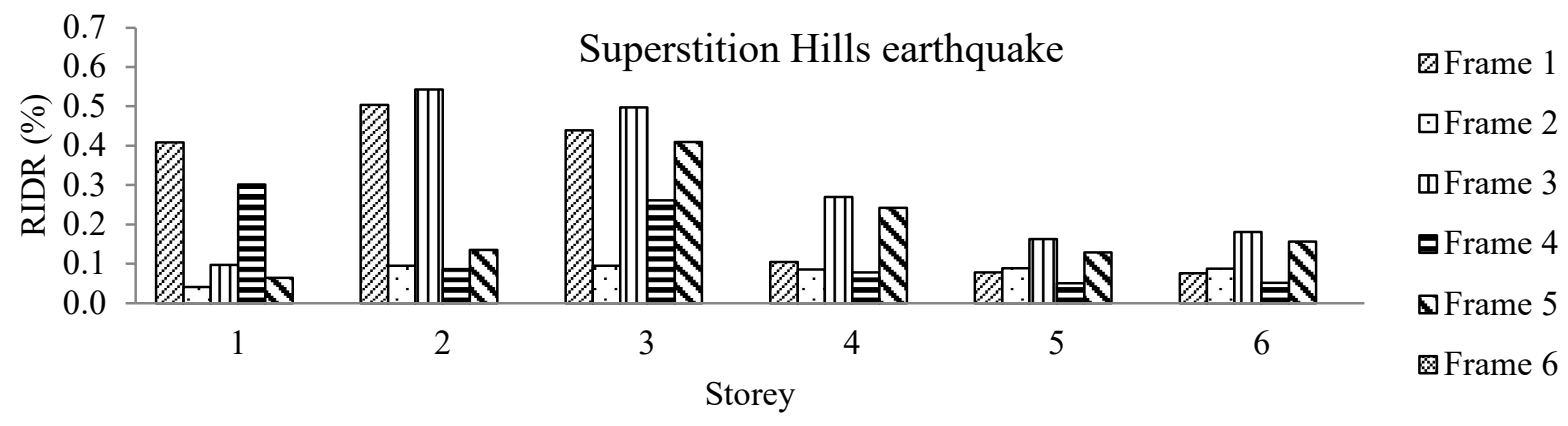

b) RID

Figure 19: Storey drifts for Superstition Hills earthquake [Sa(T1,5\%)=3.36g]

The damage distributions of the SMA frames are shown in Figures 20 to 24. The distributions were generally similar to Frame 1. In case of Frame 2 (Figure 20), severe damage was observed up to the $4^{\text {th }}$ storey due to Superstition Hills record, up to the $3^{\text {rd }}$ storey for Imperial and Tabas records, and up to the $2^{\text {nd }}$ storey for Loma and Northridge records. Using SMA in the first floor (Frame 3) caused failure of the four columns of the $1^{\text {st }}$ to $3^{\text {rd }}$ stories as well as the $5^{\text {th }}$ storey considering Imperial record. It resulted in failure of the $1^{\text {st }}, 2^{\text {nd }}$ and $4^{\text {th }}$ stories due to Superstition Hills record. Frame 4 showed better damage distribution (Figure 22) compared with Frame 3 (Figure 21) due to Imperial, Tabas, Northridge and Superstition Hills records. In case of Frame 5, severe damage occurred in the first 3 storeys while reduced damage was observed in the top three storeys as shown in Figure 23. Using SMA braces in the interior bays along the frame height (Frame 6) changed the force distribution keeping the $1^{\text {st }}$ storey as the severely damaged storey. Extensive Damage is also 
observed in the first three stories for Imperial and Superstition Hills records and the first and second stories for Tabas, Loma, and Northridge earthquakes.

The damage distribution of Frame 2 (Figure 20) and Frame 6 (Figure 24) are further compared with that of Frame 1 (Figure 11). The comparison explains that both Frames 2 and 6 show almost similar damage distributions in terms of beam and column yielding for the considered earthquakes. Use of SMA will increase the cost of BR braces but will reduce the retrofitting cost of the structures after the seismic event. This will be an investment to have a sustainable structure. Considering the cost of SMA materials at one hand and the seismic performance in terms of MID, MRID and damage distribution on the other hand, Frame 6 can be judged as the most suitable solution. 


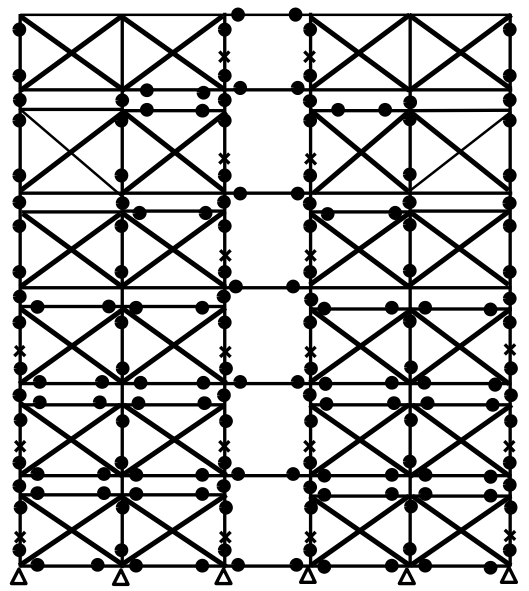

a) Imperial, $\mathrm{Sa}(\mathrm{T} 1,5 \%)=3.84 \mathrm{~g}$

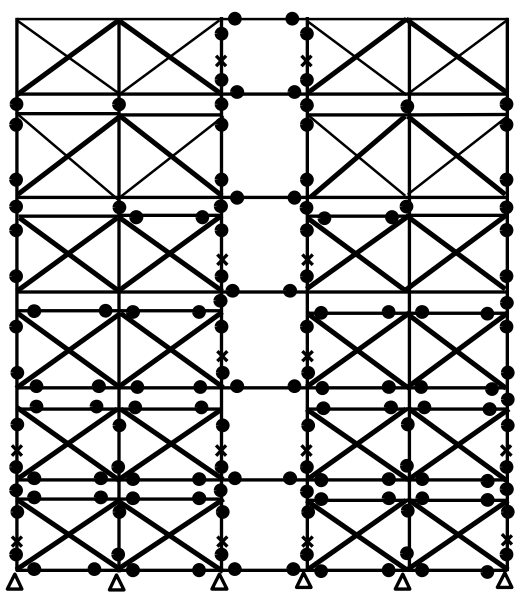

c) Loma, $\mathrm{Sa}(\mathrm{T} 1,5 \%)=3.95 \mathrm{~g}$

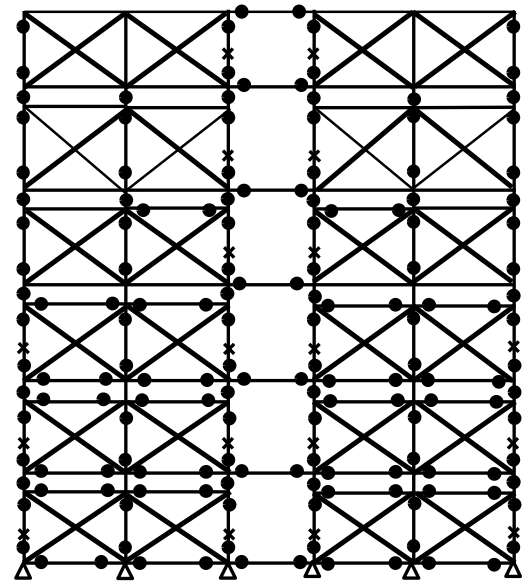

b) Tabas, $\mathrm{Sa}(\mathrm{T} 1,5 \%)=5.95 \mathrm{~g}$

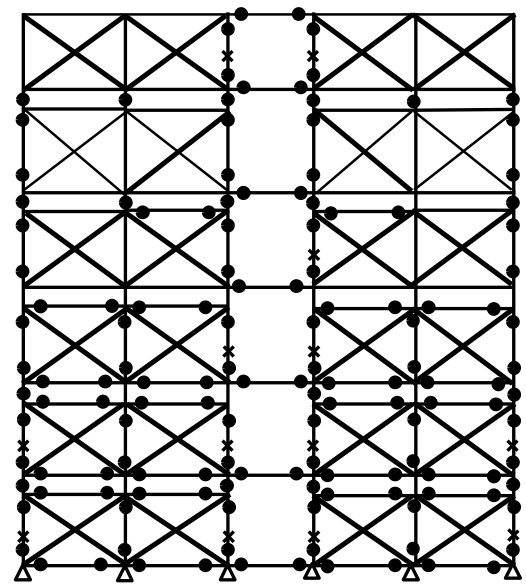

d) Northridge, $\mathrm{Sa}(\mathrm{T} 1,5 \%)=2.81 \mathrm{~g}$

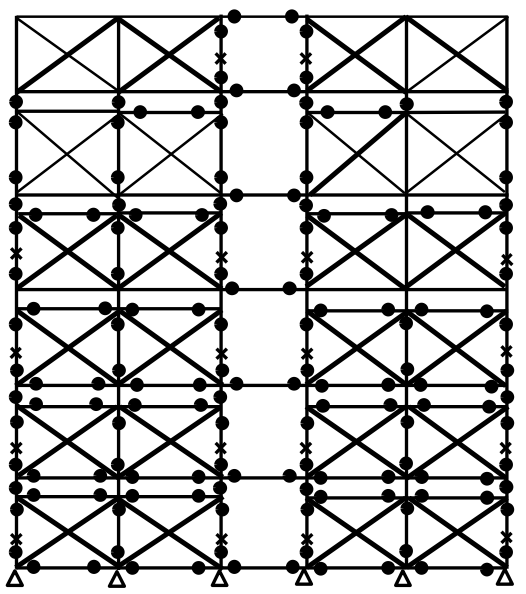

- Yielding

$\times$ Failure

e) Superstition Hills, Sa (T1, 5\%) =3.36g

Figure 20: Damage distribution of Frame 2 


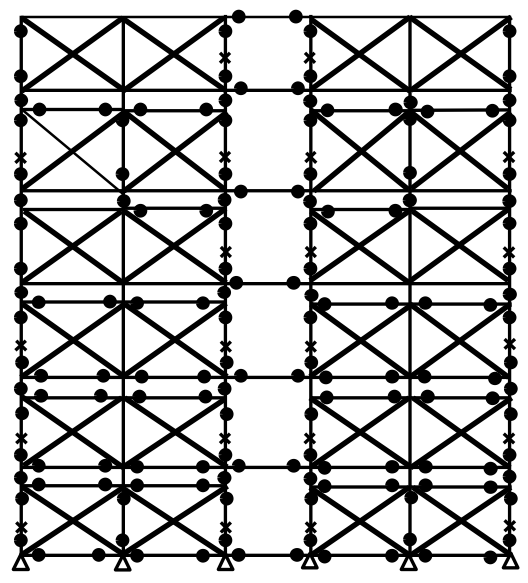

a) Imperial, $\mathrm{Sa}(\mathrm{T} 1,5 \%)=3.84 \mathrm{~g}$

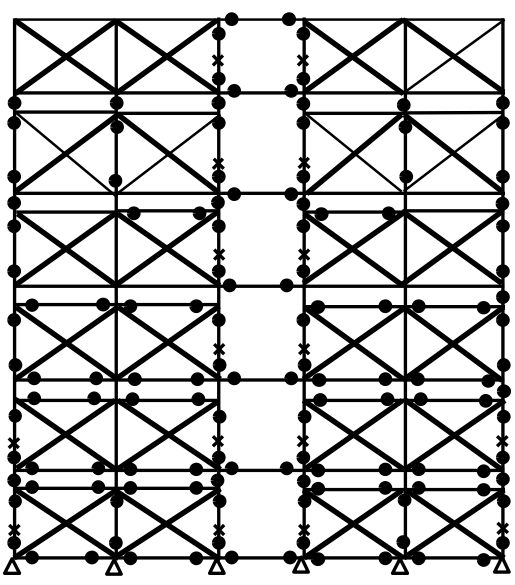

c) Loma, Sa $(\mathrm{T} 1,5 \%)=3.95 \mathrm{~g}$

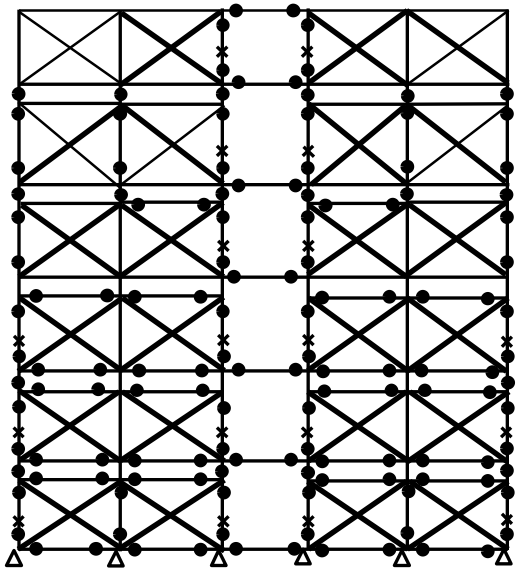

b) Tabas, $\mathrm{Sa}(\mathrm{T} 1,5 \%)=5.95 \mathrm{~g}$

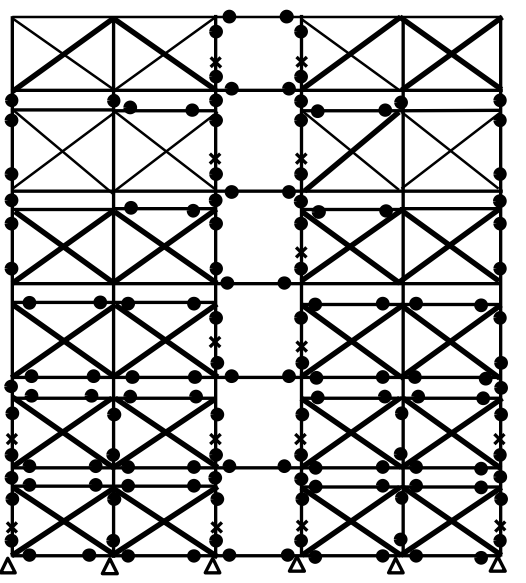

d) Northridge, $\mathrm{Sa}(\mathrm{T} 1,5 \%)=2.81 \mathrm{~g}$

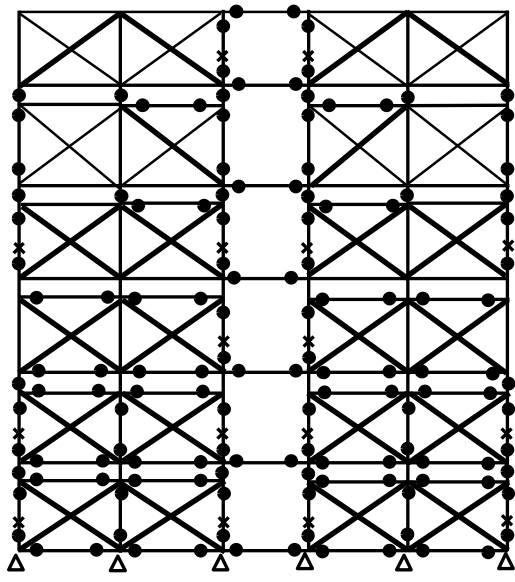

- Yielding

$\times$ Failure

e) Superstition Hills, $\mathrm{Sa}(\mathrm{T} 1,5 \%)=3.36 \mathrm{~g}$

Figure 21: Damage distribution of Frame 3 


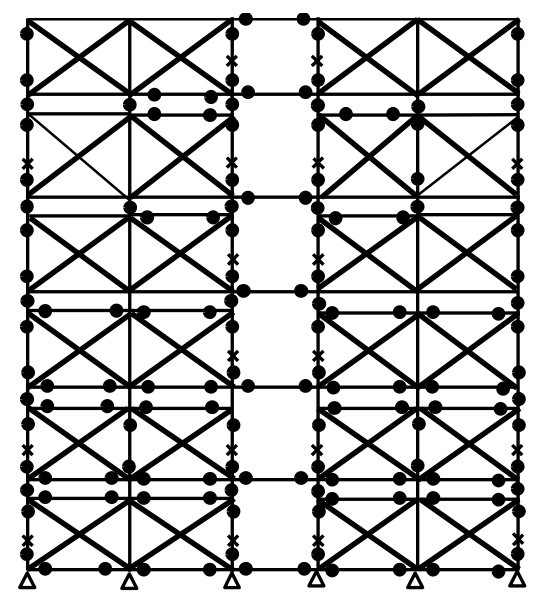

a) Imperial, $\mathrm{Sa}(\mathrm{T} 1,5 \%)=3.84 \mathrm{~g}$

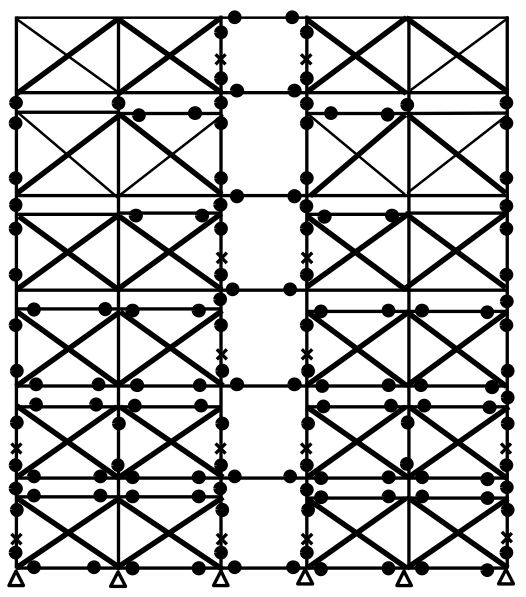

c) Loma, $\mathrm{Sa}(\mathrm{T} 1,5 \%)=3.95 \mathrm{~g}$

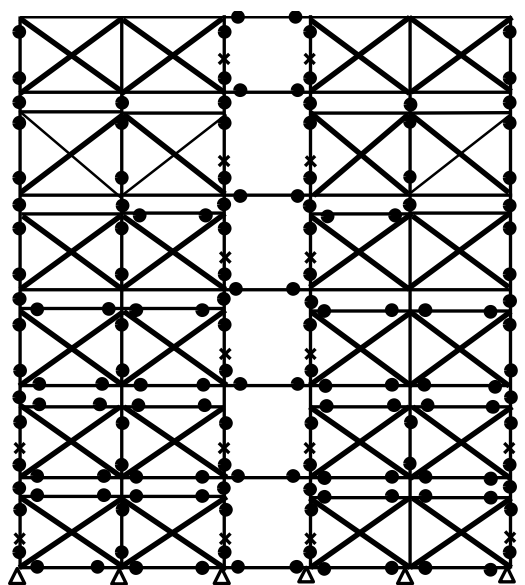

b) Tabas, $\mathrm{Sa}(\mathrm{T} 1,5 \%)=5.95 \mathrm{~g}$

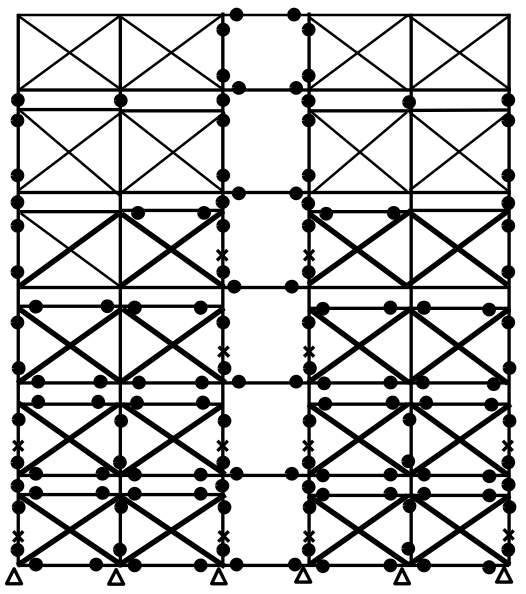

d) Northridge, $\mathrm{Sa}(\mathrm{T} 1,5 \%)=2.81 \mathrm{~g}$

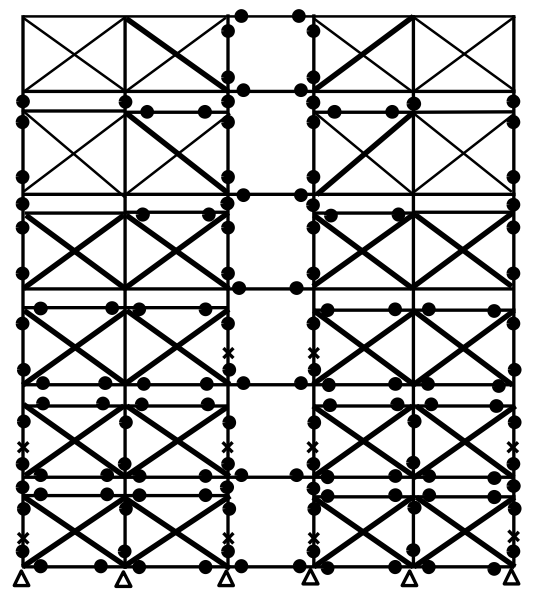

- Yielding

$\times$ Failure

e) Superstition Hills, $\mathrm{Sa}(\mathrm{T} 1,5 \%)=3.36 \mathrm{~g}$

Figure 22: Damage distribution of Frame 4 


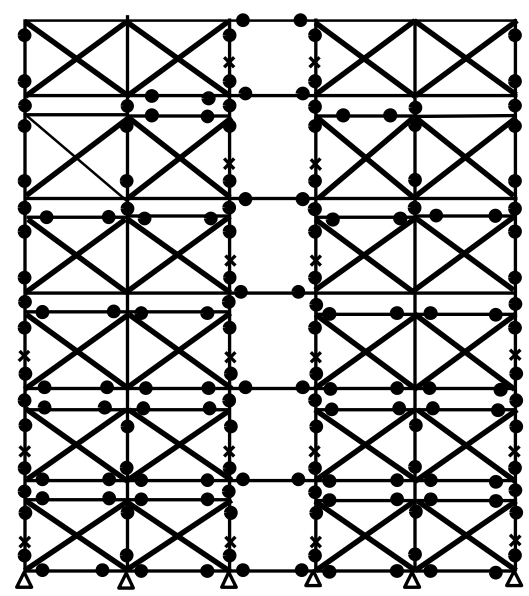

a) Imperial, $\mathrm{Sa}(\mathrm{T} 1,5 \%)=3.84 \mathrm{~g}$

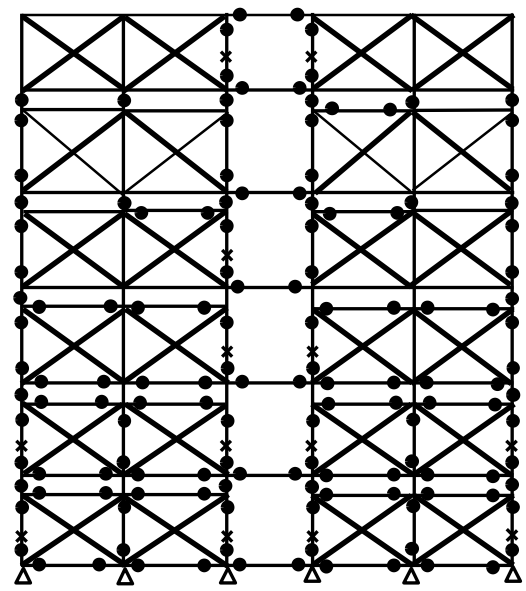

c) Loma, $\mathrm{Sa}(\mathrm{T} 1,5 \%)=3.95 \mathrm{~g}$

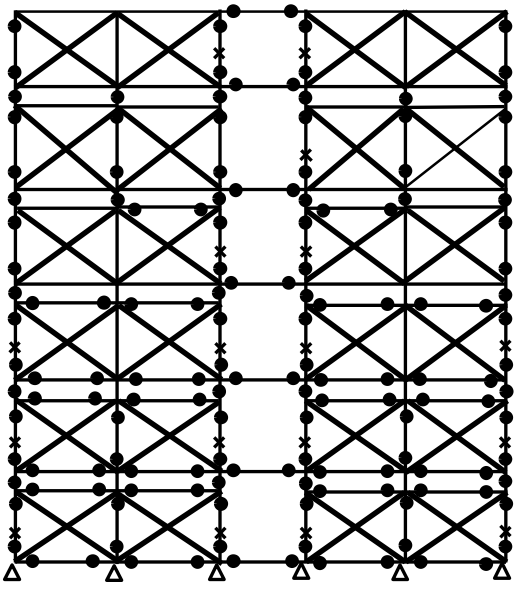

b) Tabas, $\mathrm{Sa}(\mathrm{T} 1,5 \%)=5.95 \mathrm{~g}$

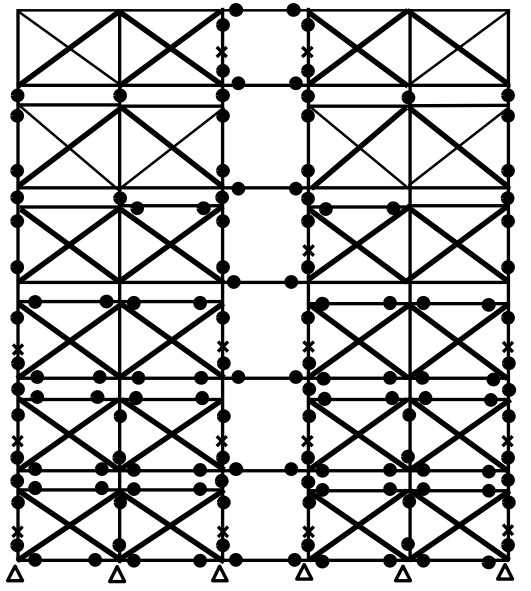

d) Northridge, $\mathrm{Sa}(\mathrm{T} 1,5 \%)=2.81 \mathrm{~g}$

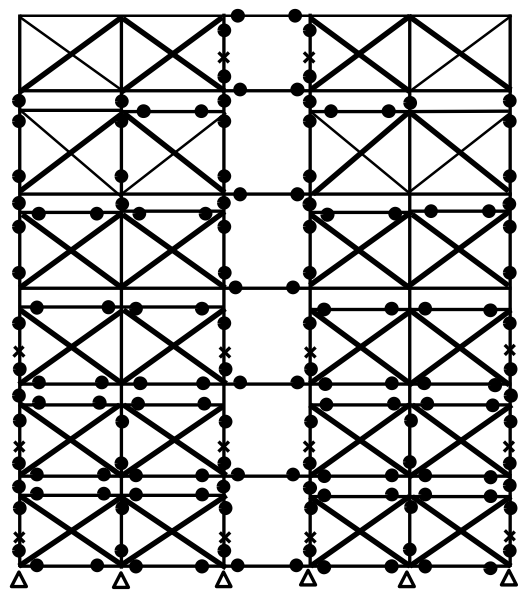

- Yielding

$\times \quad$ Failure

e) Superstition Hills, $\mathrm{Sa}(\mathrm{T} 1,5 \%)=3.36 \mathrm{~g}$

Figure 23: Damage distribution of Frame 5 


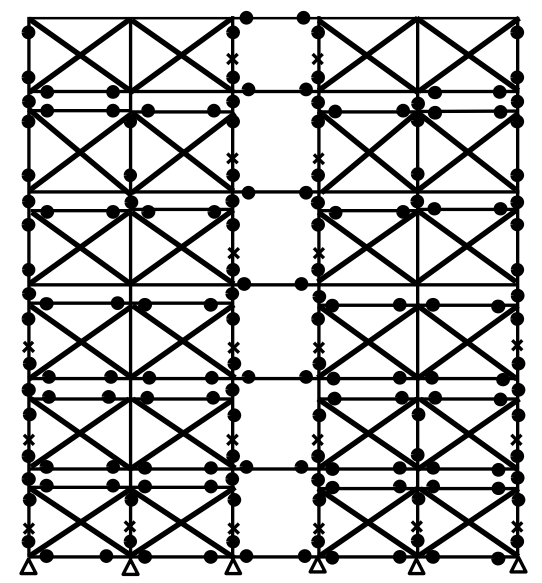

a) Imperial, $\mathrm{Sa}(\mathrm{T} 1,5 \%)=3.84 \mathrm{~g}$

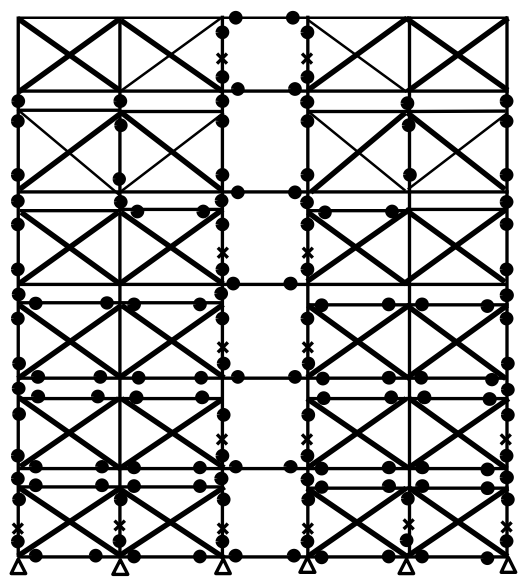

c) Loma, $\mathrm{Sa}(\mathrm{T} 1,5 \%)=3.95 \mathrm{~g}$

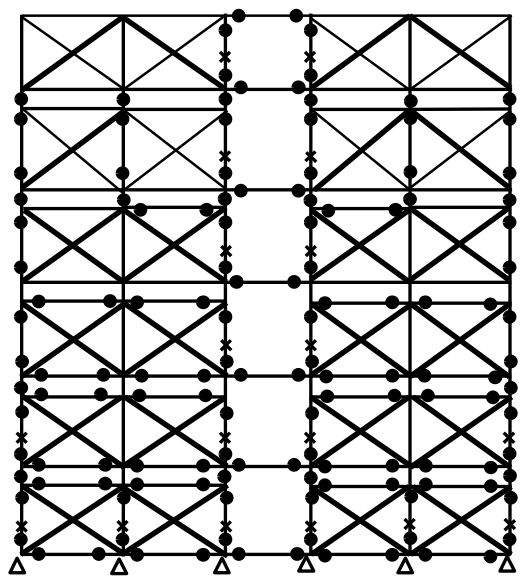

b) Tabas, $\mathrm{Sa}(\mathrm{T} 1,5 \%)=5.95 \mathrm{~g}$

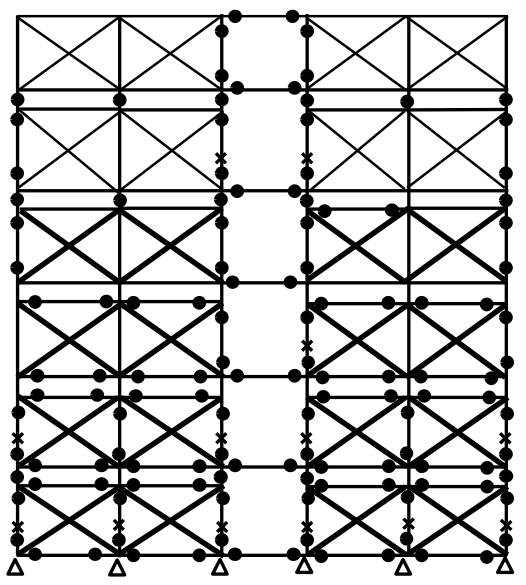

d) Northridge, $\mathrm{Sa}(\mathrm{T} 1,5 \%)=2.81 \mathrm{~g}$

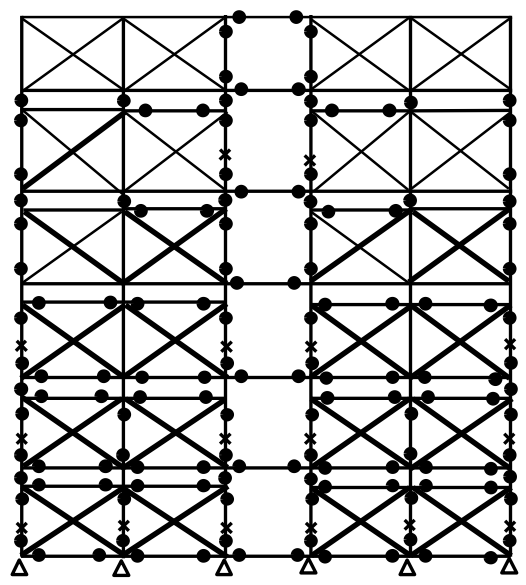

- Yielding

$\times$ Failure

e) Superstition Hills, $\mathrm{Sa}(\mathrm{T} 1,5 \%)=3.36 \mathrm{~g}$

Figure 24: Damage distribution of Frame 6 


\section{CONCLUSION}

The seismic performance of MSBF equipped with superelastic SMA braces is investigated in this paper in terms of MID, MRID and damage scheme. The modeling technique of MSBF was validated using the experimental results available in literature. A six storey MSB was then considered as a case study. IDA analysis was first conducted on a MSBF with steel braces using five different ground motions scaled to different intensities. Then, five different schemes of SMA braces were investigated. The SMA braces were designed such that the natural period of vibrations remained unchanged. Nonlinear dynamic analyses of the five SMA frames were conducted using the same records scaled to the level that caused failure to the MSBF with steel braces. The seismic performance of the steel MSBF was compared with the SMA-MSBF frames in terms of MID, MRID and damage schemes. The specific conclusions drawn from the results of this study are summarized below.

- The MIDs of SMA frames are not affected significantly by using SMA braces instead of steel braces. The increase in MID of the considered SMA frames varied from $0.34 \%$ to $8.77 \%$.

- The MRID is highly affected by the location of the SMA braces. The study highlighted the need to use SMA braces at all floors. Replacing all the steel braces by SMA braces reduced the RID by $98.5 \%$.

- The seismic performance of the MSBF can be improved by using SMA braces at the right locations. Among all SMA frames, the highest reduction of MRID occurred in Frame 2 where all braces were replaced by SMA braces (79.67\% to 98.5\%). Frame 6 where SMA braces were used in the interior bays along the building height had provided significant 
reduction in MRID (63.5\% to $84.9 \%)$. Frame 6 is considered a better economical solution based on cost, MID, MRID, and damage distribution as compared to other frames.

- Beams and columns in the unbraced bays of MSBF were severely damaged considering all ground motions. Special care is required to design these members to facilitate the redistribution of forces after yielding of braces.

- Future research is needed to examine other brace types as well as other modeling techniques that account more accurately for the vertical module connections.

\section{LIST OF NOTATIONS}

$\begin{array}{ll}A^{\text {SMA }} & \text { Area of SMA braces } \\ A^{\text {STEEL }} & \text { Area of steel braces } \\ b_{f} & \text { Flange width } \\ E^{\text {STEEL }} & \text { Modulus of elasticity, steel } \\ E^{\text {SMA }} & \text { Modulus of elasticity, SMA } \\ \text { Fy } & \text { Yield stress of steel } \\ H & \text { Web height } \\ K & \text { Stiffness of braces } \\ L^{\text {SMA }} & \text { Length of SMA braces } \\ L^{\text {STEEL }} & \text { Length of Steel braces } \\ \text { M }_{C L x} & \text { Lower bound flexural strength of the member about the x-axis. } \\ M_{C L y} & \text { Lower bound flexural strength of the member about the y-axis. } \\ M_{U F X} & \text { Bending moment in the member about the x-axis } \\ M_{U F Y} & \text { Bending moment in the member about the y-axis } \\ P & \text { Axial force } \\ P_{C L} & \text { Lower bound compression strength of column } \\ P_{U F} & \text { Axial load in the member } \\ t_{f} & \text { Flange thickness }\end{array}$


$t_{\mathrm{w}}$

$\theta_{\mathrm{y}}$

$\Delta_{\mathrm{T}}$
Web thickness

yield rotation

Brace deformation at tension.

\section{REFERENCES}

1. C. D. Annan, M. A. Youssef, M.H. El Naggar, Seismic vulnerability assessment of modular steel building. J. Earthq. Eng. 13(8) (2009) 1065-1088.

2. C. D. Annan, M. A. Youssef, and M.H. El Naggar, Experimental evaluation of the seismic performance of modular steel-braced frames. Eng. Struct. 31:7(2009a) 1435-1446.

3. C. Ariyaratana, L.A. Fahnestock, Evaluation of buckling-restrained brace frame seismic performance considering reserve strength, Eng. Struct. 33 (2011), 77-89.

4. L.A. Fahnestock, R. Sause, J.M. Ricles, Seismic response and performance of buckling-restrained braced frames, J. Struct. Eng. 133 (9) (2007) 1195-1204.

5. R. Shabelli, S. Mahin, C. Chang, Seismic demand on steel braced frame buildings with bucklingrestrained braces, Eng. Struct. 25(5) (2003), 655-666.

6. J. McCormick, J. Tyber, R. DesRoches, K. Gall, H. Maier, Structural engineering with NiTi part II: Mechanical behavior and scaling, J. Eng. Mech, 133(9) (2007) 1019-1029.

7. M. Meshally, M.A. Youssef, H.A. Elfath, Use of SMA bars to enhance the seismic performance of SMA braced RC frames, Earthq. Struct. 6(3) (2014) 267-280.

8. M. Dolce, D. Cardone, R. Marnetto, M. Mucciarelli, D. Nigro, F.C. Ponzo, G. Santarsiero, Experimental static and dynamic response of a real R/C frame upgraded with SMA recentering and dissipating braces, Proc. 13th World Conference on Earthquake Engineering, Vancouver, Canada, 2004, (paper no. 2878).

9. J. McCormick, R. DesRoches, D. Fugazza, F. Auricchio, Seismic assesment of concentrically braced steel frames with shape memory alloy braces, J. Struct. Eng. 133 (2007) 862-870.

10. A. Kari, M. Ghassemieh, S.A. Abolmaali, A new dual bracing system for improving the seismic behavior of steel structures, Smart. Mater. Struct. 20 (12) (2011) 125020.

11. A.D. Cesare, F.C. Ponzo, D. Nigro, M. Dolce, C. Moroni, Experimental and numerical behaviour of hysteretic and visco-recentring energy dissipating bracing systems, Bull Earthquake Engineering, 10(5) (2012) 1585-1607.

12. Miller, D.J., "Development and experimental validation of self-centering buckling-restrained braces with shape memory alloy", M.Sc thesis, University of Illinois at Urbana-Champaign, 2011

13. M.R. Eatherton, A.L. Fahnestock, D.J. Miller, Computational study of self-centering buckling restrained braced frame seismic performance, Earthquake Eng. Struct. Dyn. 43 (2014) 1897-1914.

14. B. Asgarian, S. Moradi, Seismic performance of steel braced frames with shape memory alloy braces. J. Constr. Steel Res. 67 (2011), 65-64.

15. S. Moradi, M.S. Alam, B. Asgarian, Incremental dynamic analysis of steel frames equipped with NiTi shape memory alloy braces. Struct. Des. Tall Special Build. 23 (2014) 1406-1425.

16. J. Hu, E. Choi, Seismic design nonlinear analysis and performance evaluation of recentering buckling-restrained braced frames, Int. J. Steel. Struct. 14 (4) (2014) 683-695.

17. M. Ghassemieh, R. Kargarmoakhar, R. Response modification factor of steel frames utilizing shape memory alloys. J. Intell. Mater. Syst. Struct. 24(10) (2013) 1213-1225.

18. P. Sultana, M.A. Youssef, Seismic performance of steel moment resisting frames utilizing superelastic shape memory alloys, J. Constr. Steel. Res. 125 (2016) 239-251. 
19. CAN/CSA-S16-01, Design of Steel Structures, Canadian Standard Association, 2001.

20. NBCC 2005 National building code of Canada.

21. SeismoStruct (version 6) - A computer program for static and dynamic nonlinear analysis of framed

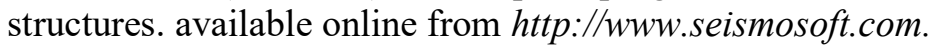

22. M. Menegotto, P.E. Pinto, Method of analysis for cyclically loaded R.C. plane frames including changes in geometry and non-elastic behaviour of elements under combined normal force and bending. Symposium on the resistance and ultimate deformability of structures acted on by well defined repeated loads, International association for bridge and structural engineering, Zurich, Switzerland, (1973) 15-22.

23. FEMA 356, Prestandard and commentary for the seismic rehabilitation of buildings, Federal emergency management agency, 2000.

24. F. Auricchio, E. Sacco, A one-dimensional model for superelastic shape-memory alloys with different elastic properties between austenite and martensite, Int. J. Nonlin. Mech. 32 (1997) 11011114.

25. D. Fugazza, Shape-memory alloy devices in earthquake engineering: mechanical properties, constitutive modelling and numerical simulations, Master's thesis, European school for advanced studies in reduction of seismic risk (ROSE School), Pavia, Italy. 2003.

26. R. DesRoches, J. McCormick, M. Delemont, Cyclic Properties of superelastic shape memory alloy wires and bars. Journal of Structural Engineering, 130(1) (2004) 38-46.

27. M. Wakabayashi, C. Matsui, K. Minami, I. Mitani, Inelastic behavior of Full-scale steel frames with and without bracings, Bulletin of the disaster prevention research institute, 24(1) (1974) 1-23.

28. J. Googins, S. Salawdeh, Validation of nonlinear time history analysis for single-storey concentrically-braced frames using full-scale shake table tests, Earthq. Eng. Struct. Dyn. 42(8) (2013) 1151-1170.

29. A. D'Aniello, G.L.M. Ambrosino, F. Portioli, R. Landolfo, Modelling aspects of the seismic response of steel concentric braced frames. Steel. Compos. Struct. 15(5) (2013) 539-566.

30. PEER ground motion database, Pacific earthquake engineering research center, University of California, Berkeley. USA, 2013, http://ngawest2.berkeley.edu/. 